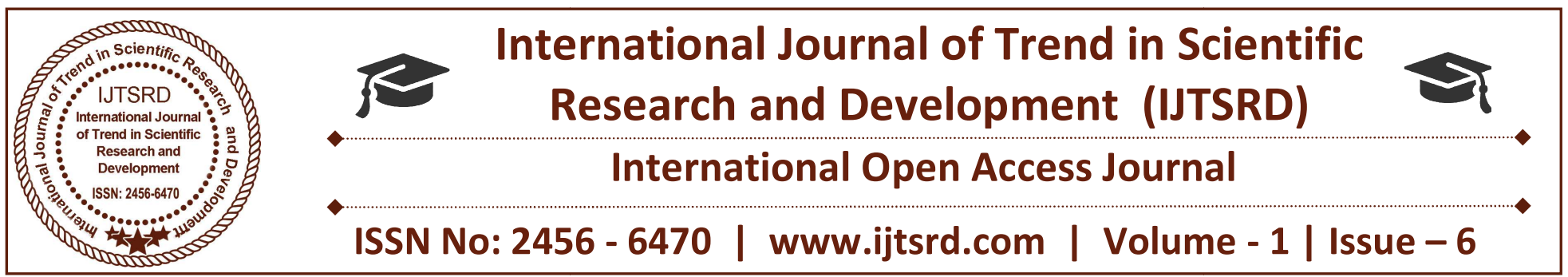

\title{
Potential And Actual Therapeutic and Medicinal Applications of Marine Macro Algae: A Review
}

\author{
Suparna Roy \\ Centre of Advanced Study (C.A.S) in Marine \\ Biology, Faculty of Marine Sciences, Annamalai \\ University, Tamilnadu
}

\author{
P. Anantharaman \\ Centre of Advanced Study (C.A.S) in Marine \\ Biology, Faculty of Marine Sciences, Annamalai \\ University, Tamilnadu
}

\section{ABSTRACT}

Seaweeds are a natural renewable resource, they are also a naturally, rich with structurally unique and diverse secondary metabolites. From the point of convenience, seaweeds are grossly grouped as the Chlorophyta, Phaeophyta and Rhodophyta on the basis of their major photosynthetic pigments. The seaweeds are a source of chemical diversity including pigments, polysaccharides, organic, and inorganic compounds, some of which find uses as animal fodder, food, nutraceuticals, pharmaceuticals, and cosmeceutical. Therapeutically, selected marine macro algae have the potential to be utilized in the treatments of: cardiovascular diseases, diabetes, obesity, viral diseases (especially HPV and HIV), cancers, and disorder of the gastro-intestinal tract (GIT), hepatic diseases, anti-inflammatory issues, some seaweeds have high levels of calcium carbonate (especially coralline algae) so applicable to treat the osteoporosis and some seaweed are used to make cosmetics which is applicable to treat the skin disease as well as normally used for glowing and taking care of normal skin health. Certain seaweeds have high levels of antioxidants such as poly phenolics, vitamins and fatty acids (especially omega- 3 fatty acids) and these inhibit the oxidation of the low-density lipoproteins in the cell membrane. Vitamins from some seaweed act as immune-stimulants and are also known to help in bone development. Some red algae have been shown to have more antihypertensive activity than that reported for both brown and green algae. Some seaweed also has been reported for having anti-coagulating and anti-hemorrhagic activities. Due to presence of high micronutrients and minerals in some specific seaweed, diet supplement with that particular seaweeds increase haemoglobins in blood and directly reduce anaemia. Some seaweed composed cosmetics find place as herbal skin care product in market. The aim of this review is to accumulate in brief, the therapeutics and medicinal uses of seaweed on the mentioned diseases.

Keywords: Marine macro algae, seaweeds, therapeutics applications, medicinal uses

\section{Introduction:}

Some edible seaweed serves as food items and ingredients of various foods for huge population of people, in different parts of the World especially Asia, Ireland and Wales (Mouritsen et al. 2013). Historically, it has been reported that some seaweed are often been used as food for sick people due to their therapeutic benefits (Chapman et al. 1980). It has been reported that some seaweed species have been used for human consumptions and medicinal purposes since $300 \mathrm{BC}$ in China, Korea and Japan and these two countries are the main contributors of edible and medicinally important seaweeds in the world production-consumption scenario. Some edible seaweed such as Gracilaria spp, Ulva spp. Ecklonia cava, Porphyra spp. have been used in jelly, soup and salad in some countries such as Malaysia, Thailand, Korea, Singapore, and Indonesia. Traditionally, red seaweeds have been used as folk medicine as a remedy for intestinal worms, due to the presence of domoic and kainic acids in the red seaweeds as vermifuge substances. In India, Gracilaria sp. and 
Acanthophora sp. are consumed as porridge along some coastal areas (Dhargalkar et al. 2005). The seaweeds find place in $20 \%$ of Asian diets due to their unique and enchanting flavour, but only just as food additives of western diet (Carvalho et al. 2009). The biochemical constituents of seaweeds are used as to treat the world's top 10 chronic diseases such as coronary artery disease or ischemic heart disease, stroke, chronic obstructive pulmonary disease, lower respiratory infection; trachea, bronchus and lung cancers, Human Immunodeficiency Virus (HIV/AIDS), diarrheal diseases, diabetes mellitus, preterm birth complication and tuberculosis (FAO, 2012). More than 7000 marine natural products have already been isolated, $25 \%$ of which are from marine macro algae. With tremendous increase in the climate change induced severity of human diseases, it is critical to analyse the data available about the pharmacologically active metabolites from the seaweeds for better utility (Kijjoa et al. 2004).

\section{Therapeutics and medicinal utilities of green seaweeds:}

Generally, green seaweeds are used as food ingredient and are well-known for their therapeutic properties. The green seaweeds are composed of $\sim 11 \%$ protein, $\sim 36 \%$ carbohydrate, $\sim 53 \%$ ash, total lipid - 0.3-21\%, saturated fatty acids $-30-60 \%$ of all fatty acids, monounsaturated fatty acids - 5-35\% and polyunsaturated fatty acids $-18-89 \%$ along with pigments (Chlorophylls), vitamins, amino acids, minerals such as calcium, iron and phosphorus (Castro-González et al. 1996, Kumari et al. 2013). Ulvans are the main polysaccharides of green seaweeds. It has many therapeutic activities. Polysaccharides of (Ulva and Enteromorpha spp.) are of two types such as the water-soluble and insoluble ulvans, and two minor ones, a peculiar alkali-soluble linear xyloglucan and a glucuronan. Sulphate, rhamnose, aldobiouronic acid, glucose, xylose, uronic acids and glucuronic acid are the main constituents of ulvans (Lahaye et al. 1997; Mc Kinnel et al. 1962). The main repeating disaccharide units reported are ulvanobiouronic acid 3-sulfate types containing glucuronic or iduronic acid (Lahaye et al. 1997, Percival et al. 1967). The Codium species are significant sources of sulphated galactans; for example, $\quad C$. fragile and $C$. cylindricum contain sulphated arabinogalactan and sulphated glucogalactan, respectively (Love et al. 1964 \& Matsubala et al. 2001). C. yezoense has a highly ramified sulphated galactans that contain a linear backbone of 3 -linked $\beta$-d-galactopyranose residues containing short oligosaccharides branches through $(1 \rightarrow 6)$ linkages (Bilan et al. 2007). Caulerpa and Ulva have also been reported to have sulphated galactans, but the galactans are the minor components. A water-soluble heteroglycuronan from Enteromorpha compressa, composed of $(1 \rightarrow 2$, 4)-linked rhamnose, $(1 \rightarrow 4)$-linked xylose, and $(1 \rightarrow 4)$-linked glucuronic acid units and a rhamnan sulphate from Monostroma nitidum consisting of $\alpha-1$, 3-linked and $\alpha$-1,2-linked rhamnose residues have been reported (Lee et al. 2010 \& Ray et al. 2006).

\subsection{Protective activity against various viruses:} Ulvans are reportedly acting as a potent anti-viral agent, particularly against human and avian influenza virus and Herpes Simplex Virus-1 (El-Baky et al. 2009; Kaeffer et al. 1999). The polysaccharide fractions of Caulerpa sp. have high anti-HSV type-1 and HSV type-2 activity (Zhu et al. 2003). Kahalalide $\mathrm{F}$ of Bryopsis sp. has been found to be effective against HIV (Hamann et al. 1996; Haefner, 2003). Ulvan extract from Ulva lactuca inhibits Japanese encephalitis virus infection in Vero cells by blocking the viral adsorption, its entry into the cell and reduces the production of pro-inflammatory cytokines. The Ulvan extract tested in in-vivo $\mathrm{C} 3 \mathrm{H} / \mathrm{HeN}$ mice displays resistance to the paralysis and death of mice proving its activity against encephalitis virus (Chiu et al. 2012). Galactose of Codium fragile and Caulerpa racemosa is biologically active against HSV-2 (Ghosh et al. 2004). The polysaccharides extract of Ulva lactuca does have protective effect against Hepatitis virus, (Sathivel et al. 2008).

\subsection{Anti-allergic activities:}

Codium fragile and Ulva japonica inhibit degranulation of both RBL-2H3 cells and mouse eosinophils (Kimiya et al. 2008). Enteromorpha compressa reduces serum $\mathrm{IgE}$ level and proves its potential anti-anaphylactic and anti-allergic activities (Raman et al. 2004).

\subsection{Anti-parasitic activities:}

Acetone extracts of Ulva lactuca has anti-parasitic activity against Culex pipiens, a blood-sucking mosquito which is a vector of diseases of Japanese encephalitis, meningitis and urticaria (Abbassy et al. 2014). The crude extracts of Cladophora rupestris, Codium fragile, Codium tomentosoides, Ulva intestinalis and Ulva lactuca have been tested against Trypanosoma brucei rhodesiense, Trypanosoma cruzi, 
Leishmania donovani and Mycobacterium tuberculosis. The crude seaweed extracts have no activity against $M$. tuberculosis, but anti-protozoal activity against at least two protozoan species. All the algal extracts tested are active against $T$. brucei rhodesiense. Of the extracts, $C$. rupestris is the most potent one $\left(\mathrm{IC}_{50}\right.$ value $3.7 \mu \mathrm{g} / \mathrm{ml}$ ), whilst $C$. rupestris and $U$. lactuca have moderate trypanocidal activity against $T$. cruzi $\left(\mathrm{IC}_{50}\right.$ values 80.8 and $\left.34.9 \mu \mathrm{g} / \mathrm{ml}\right)$. All the four extracts have leishmanicidal activity with $\mathrm{IC}_{50}$ values ranging between 12.0 and $20.2 \mu \mathrm{g} / \mathrm{ml}$ (Spavieri et al. 2010). Ulva extract is moderately active $\left(\mathrm{IC}_{50}=34.9 \mu \mathrm{g} / \mathrm{ml}\right)$ against Trypanosoma cruzi but active as leishmanicidal ( $\mathrm{IC}_{50}=12 \mu \mathrm{g} / \mathrm{ml}$ ) (Abbassy et al. 2014).

\subsection{Anti-coagulant activities:}

Sulphated polysaccharides of seaweeds such as ulvans have potential application as anticoagulant used to prevent the blood clotting (El-Baky et al. 2009). A sulphated polysaccharide fraction $(24.62 \mathrm{IU} / \mathrm{mg})$ of Caulerpa cupressoides with high sulphate content $(23.79 \%)$ has less potent activity than heparin (193 IU/mg) (Rodrigues et al. 2011). Algae derived polysaccharides -anticoagulant activity are listed as follows.

\begin{tabular}{|l|l|l|}
\hline Compounds & Species & References \\
\hline $\begin{array}{l}\text { Sulphated } \\
\text { polysaccharides }\end{array}$ & $\begin{array}{l}\text { Ulva } \\
\text { conglobata }\end{array}$ & $\begin{array}{l}\text { Mao et al. } \\
(2006)\end{array}$ \\
\hline $\begin{array}{l}\text { Rhamnan sulphate, } \\
\text { antithrombin } \\
\text { agent. }\end{array}$ & $\begin{array}{l}\text { Monostroma } \\
\text { nitidum }\end{array}$ & $\begin{array}{l}\text { Harada et al. } \\
(1998)\end{array}$ \\
\hline $\begin{array}{l}\text { Highly sulphated } \\
\text { galacto- } \\
\text { arabinoglucan }\end{array}$ & $\begin{array}{l}\text { Codium } \\
\text { pugniformis }\end{array}$ & $\begin{array}{l}\text { Matsubara et } \\
\text { al. (2000) }\end{array}$ \\
\hline Sulphated galactan & $\begin{array}{l}\text { Codium } \\
\text { cylindricum }\end{array}$ & $\begin{array}{l}\text { Matsubara et } \\
\text { al. (2001) }\end{array}$ \\
\hline $\begin{array}{l}\text { Sulphated } \\
\text { Polysaccharides }\end{array}$ & $\begin{array}{l}\text { Caulerpa } \\
\text { racemosa }\end{array}$ & $\begin{array}{l}\text { Ghosh et al. } \\
(2004)\end{array}$ \\
\hline $\begin{array}{l}\text { Sulphated } \\
\text { Polysaccharides }\end{array}$ & $\begin{array}{l}\text { Monostroma } \\
\text { sp. }\end{array}$ & $\begin{array}{l}\text { Mao et al. } \\
(2008) \\
\text { Zhang et al. } \\
(2008)\end{array}$ \\
\hline
\end{tabular}

\subsection{Active role against various risk factor of cardiovascular disease:}

Polyunsaturated fatty acids have desirable therapeutic and health-promoting properties. Omega-3 fatty acids decrease cholesterol and lipid in the blood and reduce chances of developing the atherosclerotic lesions. Algal polysaccharides such as ulvans and fibres have hypocholesterolemic and hypolipidemic responses due to low cholesterol absorption (Simopoulos 1991; Hassan et al. 2011; Bocanegra et al. 2009). The crude polysaccharides of Ulva lactuca have antiperoxidative and anti-hyperlipidemic activities, as proved in rats induced with hepatitis by Dgalactosamine. The crude polysaccharides also reduce the atherogenic index in plasma which suggests its potential protection against cerebrovascular and ischemic cardiovascular diseases (Pengzhan et al. 2003). The polysaccharides extracted from Ulva pertusa in hot water followed by precipitation with ethanol at low dose of $125 \mathrm{mg} \mathrm{kg}-1$ exhibit optimal effect on triglycerides, but less impact on total cholesterol (TC) and low density lipoprotein cholesterol (LDL-C). Similarly, when rats are fed with dried Ulva rigida exhibits low levels of low density lipoprotein (LDL) cholesterol (Taboada et al. 2010).

\subsection{Anti-inflammatory activities:}

Biologically active steroid (3-O- $\beta$-D-glucopyranosyl cholesterol) from Ulva lactuca reduces oedema and acts as promising anti-inflammatory agent (Awad, 2000; Margret et al. 2009). In humans, phospholipase A2 (PLA2) involves in developing inflammatory diseases, and hence the compounds with inhibitory effect on PLA2 act as anti-inflammatory drugs, as reported in the case of Caulerpa prolifera (Mayer et al. 1993). Caulerpenyne, major secondary metabolite, a sesquiterpene which involves in the chemical defence of Caulerpa taxifolia acts as antiinflammatory agent (Figure-3). Caulerpenyne induces an inhibition of SK-N-SH cell proliferation. After observation, on Immune-fluorescence microscopic examination has proved that no blockage in $\mathrm{G} 2 / \mathrm{M}$ phase and there is an increase in cell death. Caulerpenyne affects the microtubule network in SK$\mathrm{N}-\mathrm{SH}$ cell line and causes a loss of neurites and a compaction of the microtubule network at the cell periphery (Barbier et al. 2002). Methanol extracts of Ulva conglobata and U. lactuca are proved to have anti-inflammatory effects in murine hippocampal HT22 cell line (Jin et al. 2006). Aqueous and methanol extracts of Caulerpa mexicana exhibit antinociceptive and anti-inflammatory activities (Bitencourt et al. 2011), and these activities are also shown by lectin and sulphated polysaccharide from Caulerpa cupressoides (Vanderlei et al. 2010). 


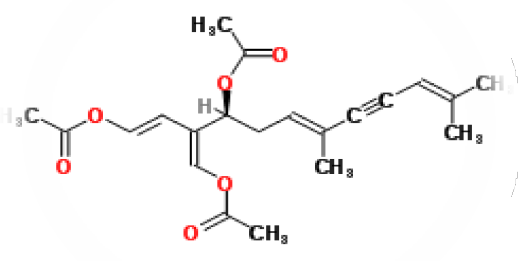

Figure 3: Caulerpenyne of Caulerpa taxifolia (https://www.ncbi.nlm.nih.gov/pubmed)

\subsection{Anti-cancer activities:}

Caulerpenyne from Caulerpa sp. is reported to have anticancer, anti-tumour, and anti-proliferating properties (Fischel et al. 1995). The poly phenols such as catechin, epicatechin, epigallocatechin, gallate and gallic acid of Halimeda sp. show anti-cancer activity (Yoshie et al. 2002). The methanolic extract of Ulva lactuca is active in regulating the tumour genesis (Lee et al. 2004). Cladophoropsis sp. has cytotoxicity to human cervical adenocarcinoma cell line (Murugan, 2011). Glycoprotein of Capsosiphon fulvescens induces apoptosis in human gastric cancer cells (Kim et al. 2012). The extracts from Ulva fasciata have cytotoxicity against colon cancer cell line and the HCT116 human colon cancer cell line by inhibiting by $50 \%$ at $200 \mu \mathrm{g} / \mathrm{ml}$. This also induces apoptosis through alteration in $\mathrm{Bcl} 2$ family protein expression, increases mitochondrial membrane permeability, and activates caspase 9 and 3 (Ryu et al. 2013).

\subsection{Potentiality for Immunomodulation:}

Ulvans act as immunostimulant. Sulphated polysaccharides from Ulva rigida induce a two-fold increase of expression of several chemokines and interleukins that result in nitrite production, prostaglandin secretion and that accelerate macrophage activities for the immunity in the host systems (Leiro et al. 2007). Caulerpa $\mathrm{sp}$. and Ulva sp. have neuroprotective properties as they check acetyl cholinesterase enzyme inhibitory activity which controls the Parkinson's disease, Alzheimer's disease, multiple sclerosis etc. (Pangestuti and Kim, 2011).

\subsection{Anti-diabetic properties:}

Water extracts of green algae are useful as therapy for neuropathies associated with diabetes and preservation of renal function and vasculopathies (Daniels et al. 2004).
1.11. Tuberculosis: Depsipeptides kahalalide $A$ and $F$ from Bryopsis sp. have in-vitro activity against Mycobacterium tuberculosis (El Sayed et al. 2000).

\section{Therapeutics and medicinal utilities of brown seaweeds:}

Generally, brown seaweeds have excellent therapeutic and medicinal properties against deadliest disease such as cardiovascular disease, diabetes, HIV and immune disease etc. (Gamal-Elden et al. 2009). The brown seaweeds are composed of chlorophylls a, c, carotene, proteins, amino acids, peptides, poly phenols, fatty acids, free manitol, minerals including iodine and minerals polysaccharide, alginic acid and alginate, cellulose, manitol and sulphated polysaccharides such as fucoidans, fucoxanthin and laminarins (Chapman et al. 1980). Alginates are the principle cell wall acidic polysaccharides widely distributed in brown algae including Laminaria hyperborea, Laminaria digitata, Laminaria japonica, Ascophyllum nodosum, and Macrocystis pyrifera. Alginates are linear anionic polysaccharides, composed of a main backbone of poly-D-glucuronic acid ( $G$ blocks) and poly-D-mannuronic acid (M blocks), together with D-guluronic acid and Dmannuronic acid (GM blocks) usually alternating (Draget et al. 2006 and Wang et al. 2012). Laminarins consist of a backbone of (insoluble) $\beta$-1, 3-bonded glucopyranoses of which some carry $\beta$-1, 6-branched glucose residues. Mannitol, the alcohol form of mannose, is the first product of photosynthesis in brown macro algae. Primarily, fucoidans from Laminariaceae are composed of a backbone of $\alpha-1,3-$ linked-L-fucopyranose residues with sulphate substitutions at C-4 and occasionally at the C-2 position in addition to 2-O- $\alpha$-L-fucopyranosyl, other glycosyl such as galactose, and/or acetate substitutions (Obluchinskaya et al. 2008 \& Bilan et al. 2010). Fucans are high molecular weight sulphated polysaccharides, usually classified into three major groups: glycuronogalactofucans, fucoidans, and xylofucoglycuronans. These polymers occur in the intercellular tissues or mucilaginous matrix of brown algae. They are widely distributed in the cell walls of brown algae and as a huge source of L-fucose with different portions of neutral sugars such as galactose, glucose, mannose, and uronic acid that can occur in the polymer. 


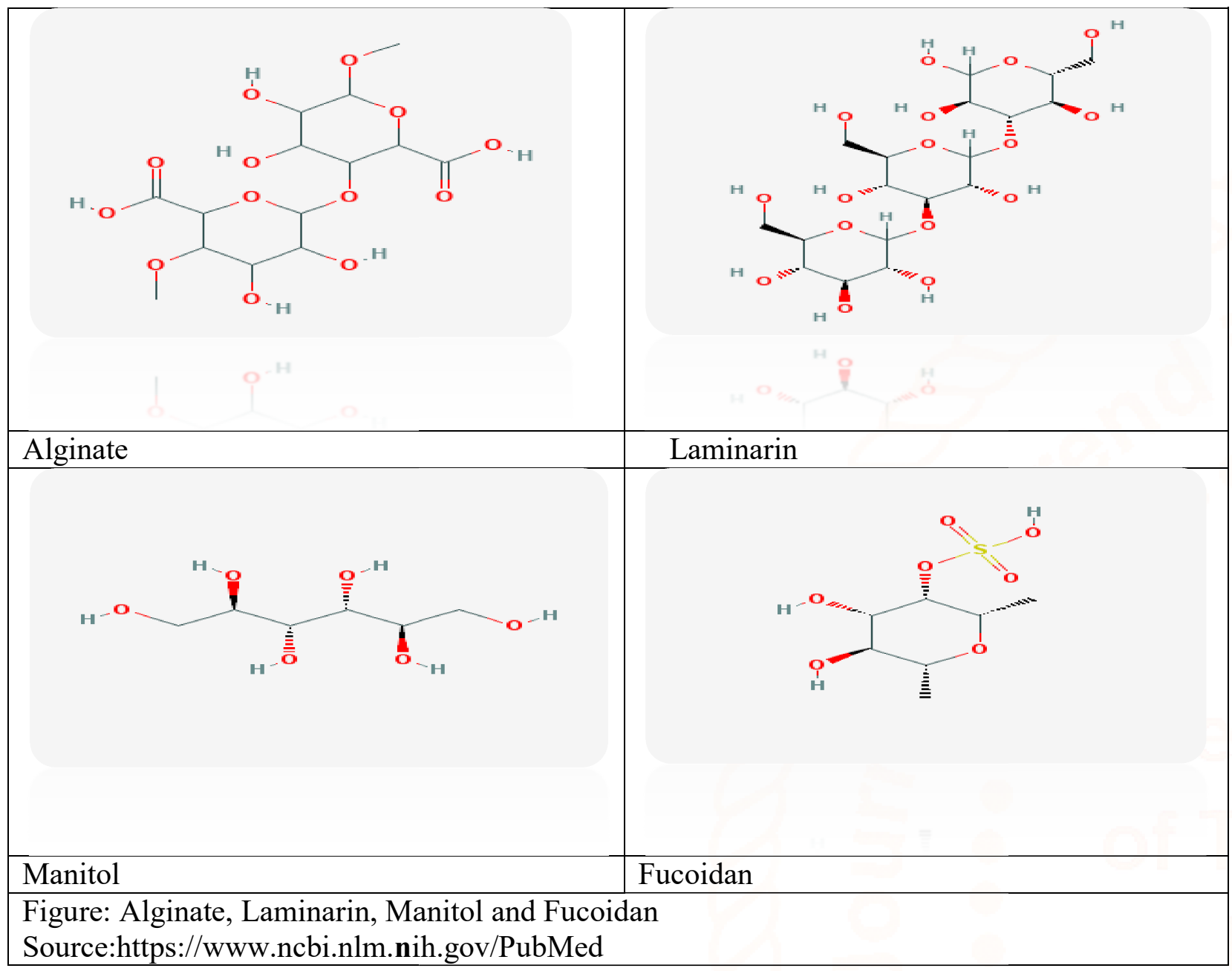

\section{1. Anti-viral Activities:}

Ingestion of Undaria sp. deactivates herpes infections. A patient with an ACV-resistant HSV II recurrent infection experiences no symptoms for 3 months when Undaria supplement is given to a patient who is infected with genital herpes (Cooper et al. 2002). Diphlorethohydroxycarmalol from Ishige okamurae has an inhibitory effect on HIV-1; HIV-1 reverse transcriptase and integrase respectively with IC values of $9.1 \mu \mathrm{M}$ and $25.2 \mu \mathrm{M}$ (Ahn et al. 2006). A phloroglucinol derivative, $6,6^{\prime}$ bieckol naturally occurring in Ecklonia cava, inhibits HIV-1 induced syncytia formation, lytic effects, and viral p24 antigen production (Artan et al. 2008). The sulphated fucans of Dictyota mertensii, Lobophora variegata, Spatoglossum schroederi and Fucus vesiculosus inhibit HIV (human immunodeficiency virus) reverse transcriptase (RT) enzyme. The galactofucan fraction, rich in galactose, fucose, and glucose from Lobophora variegata show $94 \%$ inhibitory effect on reverse transcriptase, fucan A from Spatoglossum schroederi and Dictyota mertensii also have high inhibitory effect on RT enzyme at $1.0 \mathrm{mg} / \mathrm{mL}$, with 99.03 and 99.3\% inhibition, respectively but Spatoglossum schroederi, with galactose, fucose and high sulphate level have a lower inhibitory activity $(53.9 \%)$ at the same concentration (Queiroz et al. 2008). The sulphated fucans have been extracted from brown seaweed Cystoseira indica, exhibit a promising activity against HSV-1 and HSV-2 deprived off any cytotoxicity for Vero cell cultures (Mandal et al. 2007). The sulphated polysaccharide, fucoidans of Cladosiphon okamuranus potentially inhibits Dengue Virus-2 (DENV-2) infection. It reduces infectivity by $20 \%$. However, carboxy fucoidans in which glucuronic acid is converted to glucose attenuate the inhibitory activity on DENV-2 (Hidari et al. 2008). Some of the compounds and its anti-viral activity are listed below: 
International Journal of Trend in Scientific Research and Development (IJTSRD) ISSN: 2456-6470

\begin{tabular}{|c|c|c|}
\hline Compounds & Virus & References \\
\hline $\begin{array}{l}\text { Fucoidans, the sulphated } \\
\text { polysaccharides }\end{array}$ & $\begin{array}{l}\text { HIV (Human immune } \\
\text { deficiency virus), Herpes } \\
\text { simplex virus types (HSV-1 and } \\
\text { HSV-2) and cytomegalo virus }\end{array}$ & Witvrouw \& De Clercq, 1997 \\
\hline $\begin{array}{l}\text { Undaria extracts and } \\
\text { purified galactofucan sulphate } \\
\text { of Undaria }\end{array}$ & $\begin{array}{l}\text { Herpes Simplex Virus (HSVI) } \\
\text { and HSVII including half ACV- } \\
\text { resistant }\end{array}$ & Hoshino et al. 1998 \\
\hline Undaria extracts & $\begin{array}{l}\text { Epstein-Barr virus (EBV); HSV } \\
\text { and immune deficiency virus }\end{array}$ & Luscher-Mattli, 2000 \\
\hline $\begin{array}{l}\text { Padina arborescens and } \\
\text { Sargassum patens }\end{array}$ & HSV types 1 and 2 & Zhu et al. 2003 \\
\hline $\begin{array}{l}\text { Phlorotannins from brown } \\
\text { algae Phloroglucinol }(1,3,5,- \\
\text { tryhydroxybenzene) }\end{array}$ & Anti-HIV activity & La Barre et al. 2010 \\
\hline $\begin{array}{l}\text { Galactofucan fractions of } \\
\text { brown algae Adenocystis } \\
\text { utricularis }\end{array}$ & In vitro anti-HIV- 1 activity & Queiroz et al. 2008 \\
\hline Ecklonia cava & $\begin{array}{lcr}\begin{array}{l}\text { Inhibitory } \\
\text { reverse } \\
\text { protease }\end{array} & \begin{array}{l}\text { transcriptase } \\
\text { HIV }-1\end{array} \\
\end{array}$ & Ahn et al. 2004 \\
\hline $\begin{array}{l}\text { Fucoidan from Cladosiphon } \\
\text { okamuranus }\end{array}$ & $\begin{array}{l}\text { antiviral activity against } \\
\text { Newcastle disease virus in the } \\
\text { Vero cell line }\end{array}$ & Elizondo-Gonzalez et al. 2012 \\
\hline $\begin{array}{lll}\begin{array}{l}\text { Fucoidan } \\
\text { vesiculosus }\end{array} & \text { from } & \text { Fucus } \\
\end{array}$ & suppress HIV RT in vitro & Moen and Clark, 1993 \\
\hline Sargassum piluliferum MC26 & Anti-influenza virus compound & Akamatsu et al. 2003 \\
\hline
\end{tabular}

2. 2. Role for Hepatoprotection: The protective role of brown alga Padina boergesenii extract confirms its potent activity through its antioxidant actions against $\mathrm{CCl} 4$ induced free radical damage (Karthikeyan et al. 2010). Fucoidan extract from Turbinaria tricostata displays significant free radical scavenging action against DPPH and induces a hepatoprotective effect by inhibition of ROS generation (Chale-Dzul et al. 2015).

2.3. Anti-allergic activities: Allergic hypersensitivity responses are of two types such as anaphylactic reactions triggered by mast cells and asthma or rhinitis caused by ragweed antigens dominated by eosinophils. Basophils play a pivotal role in the development of immunoglobulin E ( $\mathrm{IgE}$ )-mediated chronic allergic inflammation, as an initiator rather than as an effector. So, degranulation activities of basophilic cells are used to explore the antiallergic activity. Marine algal extracts are proved to have inhibitory effects on degranulation of rat basophilic (RBL-2H3) cells and mouse eosinophils Kimiya et al. 2008. The water extracts of Ecklonia cava and Chrysymenia wightii at a concentration of $100 \mu \mathrm{g} / \mathrm{mL}$ and methanol extracts of Petalonia binghamiae, Scytosiphon lomentaria, Undaria pinnatifida, Porphyra dentata, Codium fragile and Ulva japonica at a concentration of $200 \mu \mathrm{g} / \mathrm{ml}$ inhibits more than $50 \%$ of the degranulation of RBL-2H3 cells. Some brown seaweed including Sargassum tenerimum, $S$. cervicorne, S. graminifolium, $S$. thunbergii, and Laminaria japonica have shown to have activity against hyaluronidase, which reveals their antiallergic activity (Samee et al. 2009). Sargassum hemiphyllum inhibits allergic reaction to treat of allergic inflammatory diseases, such as atopic dermatitis ( $\mathrm{Na}$ et al. 2005).

2. 4. Anticoagulant activities: Fucose extracted from Undaria pinnatifida, Laminaria sp. and Fucus 
vesiculosus act as antiviral agent as well as anticoagulant at the concentration range of 57.11 to $90 \%$, similarly with mammalian molecule, heparin sulphate (Mori et al. 1982; Nishino et al. 1994; Witvrouw et al. 1997 and Schaeffer et al. 2000). Fucoidans have antilipidemic activity in-vivo (Mori et al. 1982), by inhibiting leucocytes movement into tissues and modulating metastasis (Ritter et al. 1998; Coombe et al. 1987). Sulphated fucans from Fucus vesiculosus and Ascophyllum nodosum have been patented for anticoagulant properties as the sulphated fucans have advantages over heparin in showing a dose dependent inhibition of thrombin- induced thrombosis (Trento et al. 2001). Sulphated polysaccharides from Dictyota cervicornis have been evaluated for their anticoagulant activity to activate partial thromboplastin time (APTT) test. The sulphated polysaccharides display the highest activity, prolong the coagulation time to double the baseline value in the APTT with only $0.01 \mathrm{mg} / 100 \mathrm{microl}$ of plasma, 1.4-fold lesser than Clexane, a low molecular weight heparin (Costa et al. 2009).

\section{5. Active potentiality against various risk factors} of cardiovascular disease: The changeable risk factors associated with coronary heart disease and stroke is high blood pressure (hypertension), high cholesterol, obesity, diabetes physical inactivity, unhealthy diet and harmful use of alcohol. There are many reports on the positive activity of brown seaweeds against the risk factors of cardiovascular disease.

\begin{tabular}{|l|l|l|l|}
\hline Species & Activity & Extract/compounds. & References \\
\hline $\begin{array}{l}\text { Eckolnia bicyclis } \\
\text { and Eckolnia cava }\end{array}$ & Anti-diabetic & Dieckol & $\begin{array}{l}\text { Okada et al. 2004 and } \\
\text { Lee et al. 2009 }\end{array}$ \\
\hline Ishige okamurae & Anti-diabetic & Diphlorethohydroxycarmalol & Heo et al. 2009 \\
\hline Eckolnia stolonifera & Anti-diabetic & Phlorofucofuroeckol-A & Iwai, 2008 \\
\hline Eckolnia stolonifera & $\begin{array}{l}\text { Anti- } \\
\text { hypertension }\end{array}$ & Eckol Phlorofucofuroeckol A & Jung et al. 2006 \\
\hline
\end{tabular}

Phlorotannins from brown seaweeds have a marked ACE inhibitor activity with (Jung et al., 2006). The ethanol extracts of E. stolonifera, E. cava, $P$. siliquosa, $U$. pinnatifida, and $G$. tenella exhibited significant inhibitory activity of $50 \%$ against ACE at a concentration of $163.93 \mu \mathrm{g} / \mathrm{ml}$. Moreover, phlorotannins such as eckol, phlorofucofuroeckol A, and dieckol, which derived from E. stolonifera, have shown considerable inhibitory activity against ACE. Among them, phlorofucofuroeckol $\mathrm{A}$ is the strongest ACE inhibitor with an IC50 value of $12.74 \mu \mathrm{M}$ (Jung et al., 2006). The intravenous applications of fucogalactan fractions extracted from Undaria reduce lipid clearance time indirectly and minimise the risk of cardiovascular disease development (Mori et al. 1982). Fucoidans recognize blocking of the macrophage scavenger receptor with uptake of low density lipoprotein (Yokota et al. 1988). An aqueous ethanolic extract of Ascophyllum nodosum inhibits rat intestinal a-glucosidase (IC50 $=77 \mathrm{mg} / \mathrm{mL}$ ) and stimulates basal glucose uptake into 3T3-L1 adipocytes during a 20-minute incubation by about 3fold (at $400 \mathrm{mg} / \mathrm{ml}$ extract) (Zhang et al. 2007). Alginate tends to bind with toxins including heavy metals and radioactive isotopes in the intestines and helps to flush out the toxins from the host system. Likewise, alginate reduces cholesterol from the liver, thereby alleviating fatty liver conditions. Fucoxanthin absorbs $75 \%$ of ingested fat; Saccharina latissima has high sugars and mannitol which is a blood sugar balancer

\subsection{Active potentiality against various cancers:}

Brown seaweeds have been proved to have anticancer activities on different cell lines. Laminaria, Macrocystis, Nereocystis have anti-cancer activity to liver carcinoma (HepG2) human cell lines (Murugan, 2011). Two polysaccharide fractions, SP31 and SP32 from Sargassum pallidum, display significant in-vitro antitumor activity against HepG2 cells, A549 cells, and MGC803 cells (Ye et al. 2008). The activity of Sargassum sagaminarum on keratinocytes cell line reveals its enhanced activity on apoptosis including activation of caspase-3 (Hur et al. 2008). Alginates of Sargassum vulgare are active against Sarcoma 180 cells transplanted in mice (De Sousa et al. 2007). Brown algal poly phenols, phlorotannins appraise as potent cancer chemo-preventive agent against photo 
carcinogenesis and other adverse effects of UVB exposure (Hwang et al. 2006). The extracts of brown seaweeds Hydroclathrus clathratus, Padina arborescences suppress human and monkey cancer cell lines, which is tested as tumour suppression in mouse model (Wang et al. 2008). Moreover, lowmolecular weight fucoidans from Ascophyllum nodosum have an anti-proliferative effect on both normal and malignant cells, including fibroblasts, sigmoid colon Adeno-carcinoma cells and smooth muscle cells (Vischer et al. 1991). The hetero-fucans from Sargassum filipendula exhibits anti-proliferative effects on cervical, prostate and liver cancer cells (Costa et al. 2011). The cold water extract of Sargassum oligocystum has considerable anticancer activity against tumour cells replication at concentration of $500 \mu \mathrm{g} / \mathrm{ml}$ and $400 \mu \mathrm{g} / \mathrm{ml}$ of extract on Daudi and K562 cell lines, respectively (Zandi et al. 2010); polysaccharides from Sargassum fusiforme have significant anti-tumour activity both in vitro and in vivo, and also improve the immune function in tumour bearing mice (Chen et al. 2012); the hexane fraction of methanol extract of Sargassum swartzii has also been reported for its in vitro cytotoxicity against $\mathrm{CaCO} 2$ and T47D cells (Khanavi et al. 2010).

2.6. a. Blood cancer: Leukemia is developed by sudden exposure to chemicals like benzene, smoking and genetic disorders. The bioactive substances of brown seaweeds stop proliferation of blood cells. Phlorotannins such as Fucodipholoroethol $G$ and phlorofucofuroeckol A of phlorotannins are active against allergic pathway on basophilic leukaemia cell lines ( $\mathrm{Li}$ et al. 2008).

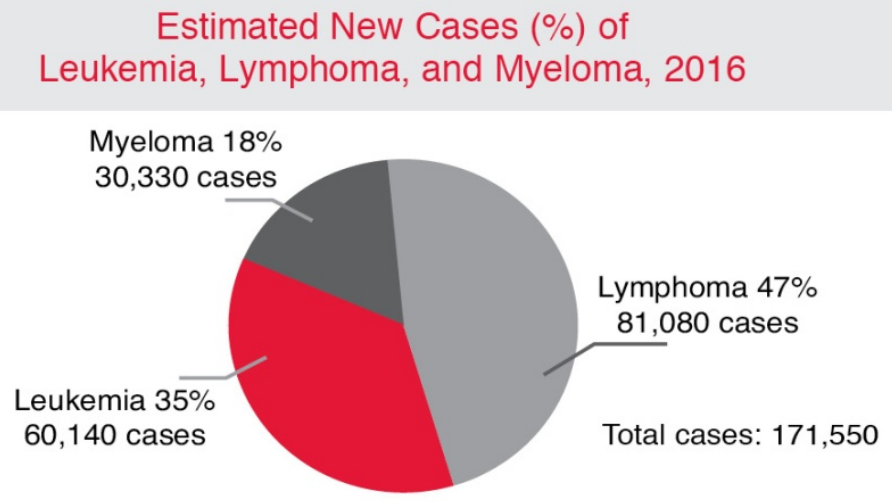

Figure 1. Source: Cancer Facts \& Figures, 2016. American Cancer Society; 2016.

The sulphated polysaccharides purified from Ecklonia cava stimulate apoptosis in-vitro and have potential anti-proliferative effect on human leukemic monocyte lymphoma cell line (Athukorala et al. 2009). HL-60 is human promyelocytic cell lines have been frequently used for anti-cancer study. Sargassum siliquastrum derived Sargachromenol E; chromene has inhibitory effects on HL-60 cells and induces apoptosis via caspase 3 activation (Heo et al. 2011). The Hydroxysargaquinone and Sargasals I and II fraction of a methanolic extract from Sargassum turtile has been demonstrated significant and minimal cytotoxicity against cultured P388 lymphocytic leukaemia cells (Numata et al. 1992). The polysaccharide E3 isolated from Sargassum latifolium shows selective cytotoxicity to lymphoblastic leukaemia 1301 cells. Polysaccharides of Sargassum linifolium have much anticancer activity against leukaemia (Gamal-Eldeen et al. 2009).
2.6. b. Colorectal cancer: According to the World Health Organization, it is the second most common cancer worldwide, after lung cancer. Colorectal cancer is one of the most common cancers in men and women and it is particularly prevalent in developed countries. The worldwide incidence of this cancer has increased steadily in recent years, and attributes to rapid changes in dietary patterns and preferences. Dietary habits influence the risk for colorectal cancer (WCRF/AICR, 2009) and search for preventive food component for tumour genesis process will be effective measure for curing colorectal cancer (Kim et al. 2010). Laminarin from Laminaria spp. inhibits the growth of colon cancer cells via Fas and IGF-IR signalling through the intrinsic apoptotic and ErbB pathways, respectively (Park et al. 2012; Park et al. 2013). Hyun et al. (1999) remarks that fucoidan $(100 \mu \mathrm{g} / \mathrm{ml})$ induces apoptosis in HCT-15 human 
colon cancer cells. Meroditerpenoids such as epitaondiol, epitaondiol diacetate, epitaondiol monoacetate, stypotriol triacetate, 14-ketostypodiol diacetate and stypotriol from Stypopodium flabelliforme have cell anti-proliferation effect on human neuroblastoma, rat basophilic leukaemia, murine macrophages, Chinese hamster fibroblasts and human colon adenocarcinoma cells (Pereira et al. 2011). Khanavi et al. (2010) noted that fractions of Sargassum swartzii are toxic to stop the proliferation of colorectal colon carcinoma cell (IC $50<100 \mu \mathrm{g} / \mathrm{mL}$ ) and breast ductal carcinoma (IC50<100 $\mu \mathrm{g} / \mathrm{mL}$ ). Glycoprotein from Laminaria japonica and fucoidans from Sargassum horney, Ecklonia cava and Costaria costata produce anti-cancer effects on human colon cancer cells (Go et al. 2010).

2.6. c. Breast cancer: Breast cancer is the most common invasive cancer in females worldwide. It accounts for $16 \%$ of all female cancers and $22.9 \%$ of invasive cancers in women. $18.2 \%$ of all cancer deaths worldwide are from breast cancer. Breast cancer usually starts off in the inner lining of milk ducts or the lobules develop tumor which can spread to other parts of the body. The methanol extract of Sargassum muticum have anti-proliferative activity for MCF-7 and MDA-MB-231 breast cancer cell lines which decrease angiogenesis, leading to decrease the cancer cell proliferation and increase apoptosis of human breast cancer cells in a time and dose dependent manner (Namvar et al. 2013). The crude extract of Fucus vesiculosus inhibits potent 4T1 cells (a mouse tumour cell line used as a model of highly metastatic), enhances apoptosis and it downregulates the expression of vascular endothelial growth factor (Xue et al. 2012). Brown seaweeds as traditional Asian diets contribute to low incidence of cancer particularly breast cancer (Kanke et al. 1996). There is a nine fold lower incidence of breast cancer in the Japanese population and an even lower incidence in the Korean population due to seaweeds consumption, as compared to the incidence in the West (Lawson et al. 2001; Teas, 1983).

2.6. d. Lung Cancer: Lung cancer is the leading cause of deaths worldwide, mainly due to smoking. Fucoidan from Fucus vesiculosus inhibits migration and invasion of human lung cancer cell via PI3K-AktmTOR pathways (Lee et al. 2012). Cystoseira mediterranea acts as inhibitor to mitotic cell division (Francisco et al. 1985) and the meroterpenes, usneoidone E and Z, from Cystoseira usneoides also have antitumor properties (Fisch et al. 2003). The diterpenes from methanol extract of Padina pavonia have anti-tumour activities against lung carcinoma (H460) (Awad et al. 2008).

\begin{tabular}{|c|c|c|}
\hline Species & Biological activity & References \\
\hline Palmaria palmata & $\begin{array}{l}\text { Phloroglucinol and its polymers, namely, } \\
\text { eckol (a trimer), phlorofucofuroeckol A } \\
\text { (a pentamer), dieckol, and 8,8-bieckol } \\
\text { (Hexamers) inhibits cancer cell proliferation. }\end{array}$ & Yuan et al. 2005 \\
\hline Acanthophora spicifera & $\begin{array}{l}\text { Crude extract has tumoricidal activity on } \\
\text { Ehrlich's ascites carcinoma cells developed in } \\
\text { mice. }\end{array}$ & Vasanthi, 2002, 2004 \\
\hline Sargassum thunbergii & $\begin{array}{l}\text { Crude extract has Antitumor activity, inhibition } \\
\text { of tumour metastasis in rat mammary Adeno } \\
\text { carcinoma cell ( } 13762 \text { MAT). }\end{array}$ & $\begin{array}{l}\text { Zhuang et al. } 1995 \quad \& \\
\text { Coombe et al. } 1987\end{array}$ \\
\hline Ascophyllum nodosum & $\begin{array}{l}\text { Fucoidans : Anti-proliferative, Anti-tumour, } \\
\text { anticancer, anti-metastatic, and fibrinolytic }\end{array}$ & $\begin{array}{l}\text { Vischer et al. } 1999 \& \\
\text { Religa et al. } 2000\end{array}$ \\
\hline
\end{tabular}

\section{6. e. Role in Immunomodulating:}

Immunomodulating is any change in the immune response and may involve induction, expression, and amplification of any part or phase in the immune response which leads to some change in immune cells like B-cells, T-cells, macrophages, neutrophils, mast cells, eosinophils, basophils and natural killer cells. Fucoidans enhance both innate and adaptive immune response by promoting tumoricidal activities by macrophages, natural killer cells, and T-helper cells (Li et al. 2008). The extracts of Sargassum linifolium inhibit about $60 \%$ of induced-DNA damage which has 
been measured by comet assay, have antiinflammatory activity, enhance macrophage proliferation, inhibit nitric oxide (NO.), COX-2 and show selective toxicity against lympho-blastic-anemia (Gamal-Eldeen et al. 2009). Dictyota sp. acts as neuroprotective agent and indirectly induces immune power (Pangestuti et al. 2011). The hot water extract of Sargassum hemiphyllum inhibit the cell proliferation (174\%) at $120 \mu \mathrm{g} / \mathrm{ml}$, and $\mathrm{IgM}$ secretion $(132 \%)$ at $120 \mu \mathrm{g} / \mathrm{ml}$ to HB4C5 cells (human hybridomas producing monoclonal antibody against human lung cancer). Furthermore, it suppresses the cell propagation (141\%) and phagocytosis activity $(148 \%)$ of $\mathrm{J} 774$ (murine macrophage like) cell line at $80 \mu \mathrm{g} / \mathrm{ml}$ (Hwang et al. 2010).

\subsection{Anti-inflammatory activities: Inflammatory} disorders, such as psoriasis and some types of colitis characterize an excessive presence of leukocytes which have been ameliorated by seaweed ingestion. Algal-derived fucoidans inhibit the passage of leucocytes into tissues by receptor blocking. Ritter et al. (1998) investigate fucoidans for its clinical potentiality to prevent destruction of post ischemic heart muscle by invading leucocytes and it show antiinflammatory effect. Stypoldione, an orthoquinone from Stypopodium zonale also have anti-inflammatory effect (Mayer et al. 1993). Sargassum hemiphyllum have been reported for its anti-inflammatory activity against Phorbol 12 myristate 13-acetate (PMA) and A23187-induced IL-8 and on TNF- $\infty$ secretion from human must cells (HMC-1) (Na et al. 2005), so likewise Sargassum thunbergii and Sargassum fulvellum have activity against Taphorbol myristate acetate induced ear edema erythema and blood flow (Kang et al. 2008), Sargassum micracanthum against LPS, induced RAW 264.7 macrophage (Yoon et al. 2009), Sargassum swartzii against carrageenan induced hind paw edema in rats and Peritonitis for acute and chronic inflammatory model (Hong et al. 2011), Turbinaria conoides against carrageenaninduced hind paw edema (Boonchum et al. 2011). Fucan, Sulphated polysaccharides from Sargassum vulgare acetone extract displays strong antiinflammatory action at all concentrations tested in the carrageenan-induced paw edema model, demonstrated by reduced edema and cellular infiltration (Celina et al. 2013).

2.8. Role for Negotiation of Diabetes: Laminaria digitata and Undaria pinnatifida as a food supplement have potent role against type- 2 diabetes. Seaweed ingestion as food influences glycemic control, lowers blood lipids, and increases antioxidant enzyme activities. It reduces the risk of cardiovascular diseases to type-II diabetes patients (Kim et al. 2008). Ecklonia stolonifera have strong anti-diabetic and antioxidant properties (Iwai, 2008).

2.9. Role for Neuroprotection: Microglia, a specialized form of macrophage residing with a wide distribution in the brain play a key role in host defence and tissue regeneration in the central nervous system. Dieckol, a hexameric phloroglucinol isolate from Ecklonia cava produce neuroprotective effect by microglia activation (Jung et al. 2009). Transmissible spongiform encephalopathies, or prion diseases, are fatal neurodegenerative disorders that include Creutzfeldt-Jakob disease (CJD) and GerstmannSträussler-Scheinker syndrome in humans and Scrapie, bovine spongiform encephalopathy (BSE), and chronic wasting disease in animals. The daily uptake of fucoidans might be prophylactic against prion diseases caused by ingestion of prioncontaminated materials (Doh-ura et al. 2007). Pheophytin A, purified from the Japanese brown alga Sargassum fulvellum synergizes nerve growth factor (NGF) at $3.9 \mu \mathrm{g} / \mathrm{mL}$ by a mechanism that appeared to involve activation of mitogen activated protein kinase signalling (Ina et al. 2007).

3. Rhodophyta: Red algae are the most abundant and commercially valuable group of seaweeds. Rhodophyta produce a lot of secondary metabolites with broad spectrum activities which have immense biomedical potential and therapeutic applications. Rhodophyta composed of carbohydrates, protein and lipids, fatty acids, amino acids, and pigments such as chlorophylls a, d, phycoerythrin and phycocyanins, carotenes and a number of unique xanthophylls, starch, xylans, mannans, Floridian cellulose, sulphated polysaccharides, agar, caragennans and porphyrans. The cell wall of red seaweeds accounts for up to $65 \%(w / w)$ of dry matter and comprises three domains: fibrillar wall, amorphous matrix and glycoprotein domain. Red seaweeds contain high amount of protein almost $47 \% \mathrm{w} / \mathrm{w}$ of dry matter in contrast, green algae contain moderate amounts (9-26 g protein $100 \mathrm{~g}-1$ dry weight), while brown algae display much lower protein contents (3-15 g 100 g-1 dry weight) (Galland-Irmouli et al. 1999 \& Sanchez-Machado et al. 2004). Carrageenans are mainly synthesized by red algae of the Gigartinales order (Gigartina sp., Chondrus crispus, Eucheuma sp. 
and Hypnea sp.), although they also appear in other Rhodophyta species (Campo et al. 2009). They have a $\beta$-D-galactopyranose repetitive basic structure (Aunit) and $\alpha$-D-galactopyranose (B-unit). The degree of sulfation is higher than that of agarans (GomezOrdonez et al. 2011).

3.1. Anti-viral activities: The cell wall composition of red seaweeds blocks the penetration of viruses, including HIV, Herpes, and Human Papilloma Virus. The red seaweeds have anti-viral activity HIV- \& HIV-II, so it is used as contraceptives. The galactan sulphate (GS), a polysaccharide isolated from the red seaweed Aghardhiella tenera inhibits viral-induced CPE of HIV-1 and HIV-2 in MT-4 cells with IC50 values of 0.5 and $0.05 \mathrm{~g} / \mathrm{L}$, respectively and the . The viral-induced syncytia formation in Molt-4 cells and HIV-1- or HIV-2-infected HUT-78 cells has been inhibited at GS concentrations $>5$ g/L. GS inhibits the binding of HIV-1 to cells, as well as the binding of anti-gp120 mAb to HIV-1 gp120 (Witvrouw et al. 1994; Damonte et al. 1994). Carrageenan has in-vitro antiviral activity; $\lambda$-carrageenan and partially cyclised $\mu /{ }^{\prime} 1$-carrageenan from Gigartina skottsbergii effect potently against different strains of HSV types 1 and 2 during the virus adsorption stage (Carlucci et al. 1997). Spieler, 2002 marketed Carraguard, a carrageenan-based vaginal microbicide blocks HIV and sexually transmitted disease. Agaroids, a high molecular weight galactans sulphate from Gracilaria corticata is active against HSV types 1 and 2, and it is likely due to an inhibition of the initial virus attachment to the host cell (Mazumder et al. 2002). Uncharacterised polysaccharide fractions obtained from Corallina sp., Hypnea charoides have high antiHSV types 1 and 2 while maintaining low levels of cytotoxicity (Zhu et al. 2003). Chondriamide A from Chondria atropurpurea shows anti-HSV type II activity (Palermo et al. 1992). Sulphated glucuronogalactan from red algae Schizymenia dubyi has anti-HIV activity (Bourgougnon et al. 1996). The Sulphated galactans extracted from the red algae Grateloupia filicina and GLPE obtained from Grateloupia longifolia have anti-HIV and antiretroviral activity in vitro (Wang et al. 2007). The extracts from Chondrus crispus and Gelidium cartilagineum protect body from influenza and mumps virus (Garber et al. 1958). Cryptonemia crenulata, sulphated polysaccharides i.e. galactans inhibits Dengue Virus- 2 (DENV) but have low inhibitory effect against DENV-3 and DENV-4, and it totally inactive against DENV-1 (Hidari et al. 2008).
3.2. Role for Hepatoprotection: If the liver cells get damage due to infectious agents or chemicals, then the serum levels of GPT (glutamic pyruvic transaminase) and GOT (Glutamic oxaloacetic transaminase) tend to increase significantly (Recknagel, 1967). Similarly, elevations of Creatinine and Bilurubin have been reported in the Acetaminophen induced hepato-toxicity (Ellenhorn et al. 1997). Gracilaria crassa at $200 \mathrm{mg} / \mathrm{kg}$ elevate the levels of total Bilurubin, SGOT, SGPT, LDH and ALP in Aflatoxin but aqueous extract of Gracilaria corticata $(250 \mathrm{mg} / \mathrm{kg})$ restorated it to normal level (Manoharan et al. (2008).

3.3. Anti-allergic activities: Some species of red macro algae are also known to be useful additional materials for control of allergic responses. Porphyran, a sulphated polysaccharides isolated from Porphyra tenera have been reported for its anti-allergic activity. Carpopeltis affinis has preventive role to atopic allergic reaction in vitro. The $C$. affinis $(10 \mathrm{~g} / \mathrm{ml})$ significantly alleviates the release of histamine, hexosaminidase, IL-8, and TNF-from mast cells with inhibition rates of $58.7,86.6,36.5$, and $59.4 \%$, respectively ( $\mathrm{Na}$ et al. 2005). The ethanol extract of Laurencia undulate exhibits a significant inhibition of all asthmatic reactions in OVA-induced mice and have been proven a preventive measure as allergic airway in-vivo (Jung et al. 2009; Kim et al. 2008). The suppress of allergic reactions in terms of the degranulation of RBL-2H3 cells and eosinophils have been tested to different extracts of red seaweeds such as Chrysymenia wightii, Porphyra dentata. The hot water extract of $\mathrm{C}$. wightii inhibits more than $50 \%$ of the degranulation of RBL-2H3 cells at a concentration of $100 \mathrm{mg} / \mathrm{mL}$ and more than $50 \%$ of the degranulation of RBL-2H3 cells has been inhibited by $\mathrm{MeOH}$ extracts of $\mathrm{P}$. dentata, at a concentration of $200 \mathrm{mg} / \mathrm{mL}$ (Kimiya et al. 2008).

\subsection{Role of red seaweeds against the risk factors of} cardiovascular disease: Hypnea charoides and Ulva sp. reduce the serum total cholesterol levels, but only the diet containing Hypnea decrease LDL-cholesterol values and increase high HDL levels which associate with increase longevity as well as a lower incidence of cardiovascular disease (Wong et al. 1999). PGE2 from Gracilaria lichenoides has antihypertensive properties when administered intravenously to hypertensive rats (Gregson et al. 1979). Natural carotene and carotenoid are anti-carcinogenic and it is 
also effective in controlling cholesterol and in reducing risks of heart disease (Nishino et al. 2002). Hypolipidemic activities have been identified in ethanolic extracts of Solieria robusta as shown by decreases in the serum total cholesterol, triglyceride and low density lipoprotein cholesterol levels in rats (Ara et al. 2002).

3.5. Anti-cancer activities: Natural products from marine sources are active agent for drug development to treat many types of cancer. Seaweeds contain many bioactive primary and secondary metabolites which represent about $9 \%$ of marine biomedical compounds (Molinski, 2009; Jha et al. 2004; Mayer et al. 2010). Elatol, a sesquiterpene isolated from Laurencia microcladia remarkable reduce tumour growth in C57BL6 mice (Campos et al. 2012). Mineral-rich extract of Lithothamnion calcareum is effective in suppressing growth and inducing differentiation of colon carcinoma cells (Aslam et al. 2009). The aqueous extracts of Gracilaria tenuistipitata rescue cells from undergoing apoptosis (Yang et al. 2012). Its methanolic/ethanolic extracts prove to be potent anticancer agents. The methanolic extracts of Gracilaria tenuistipitata induce apoptosis in cancer cells via enhanced ROS production and DNA damage in Ca9-22 oral cancer cell line. Interestingly, ethanolic extracts of Gracilaria tenuistipitata also have preventive effect in concentration dependent way in oral cancer cells (Yeh et al. 2012). Polyphenol-rich extract (ECME) of Eucheuma cottonii have antibreast cancer activity and it suppresses tumour growth via apoptosis induction with down regulating the endogenous oestrogen biosynthesis, and improving anti-oxidative status (Namvar et al. 2012). The alcoholic extract of Acanthophora spicifera exhibits tumoricidal activity on Ehrlich's ascites carcinoma cells developed in mice at a dose of $20 \mathrm{mg} / \mathrm{kg}$, comparable to the standard drug, 5-flurouracil (Vasanthi et al. 2004). Palmaria palmata have high antioxidant which capable of inhibiting cancer cell proliferation (Yuan et al. 2005). The compound Chondriamide-A from Chondria sp. exhibits cytotoxicity towards human nasopharyngeal and colorectal cancer cells (Palermo et al. 1992). Aqueous extracts of Gracilaria corticata and Sargassum oligocystum have anti-proliferative activity of human leukemic cell lines (Zandi et al. 2010). Porphyran, the SPs of Porphyra yezoensis induce cancer cell death via apoptosis in a dose-dependent way in vitro without affecting the growth of normal cells (Kwon and Nam, 2006). A sterol fraction extract of Porphyra dentata, a folk medicine had anti-cancer activity (Kazłowska et al. 2013). Chondria, Palmaria, and Amphiroa have high cytotoxic effect against human cervical adenocarcinoma cell line, murine leukemic cell lines, nasopharyngeal and colorectal cancer cells (Murugan, 2011).

3.6. Role for Immunomodulating: Sulphated polysaccharides isolated from two red algae Porphyra yezoensis and Gracilaria verrucosa stimulate phagocytosis and respiratory burst in mouse macrophages in-vitro and in-vivo (Yoshizawa et al. 1993, 1995, 1996).

3.7. Red seaweeds as anti-inflammatory agent: An acetylene containing fatty acid derivative from Liagora farinosa; a macrocyclic enol-ether from Phacelocarpus labillardieri have anti-inflammatory effect (Mayer et al. 1993). Gracilaria verrucosa and Gracilaria textorii also have anti-inflammatory activity (Almeida et al. 2011). Two enone fatty acids of Gracilaria verrucosa, (E)-10-Oxooctadec-8-enoic acid and (E)-9-Oxooctadec-10-enoic acid, inhibits the production of the inflammatory markers nitric oxide, TNF- $\alpha$, and IL- 6 and acts as anti-inflammatory compounds (Lee et al. 2009). Laurencia glandulifera derived neorogioltriol, a tricyclic brominated diterpenoid and Laurencia obtuse derived C15 acetogenins (12Z)-cis-maneonene-D and (12E)-cismaneonene-E, also have anti-inflammatory response (Ayyad et al. 2011). Porphyra yezoensis glycoprotein exhibits anti-inflammatory effects in LPS -stimulated macrophages (Shin et al. 2011). An aqueous extract of Gracilaria tenuistipitata suppresses virus-induced inflammation; a polysaccharide from Porphyridium sp. inhibits the replication of retroviruses (Talyshinsky et al. 2002). Sulphated polysaccharides from Delesseria sanguinea exhibit anti-inflammatory effects (Grunewald et al. 2009). Anti-inflammatory activity of red seaweeds have also been evaluated for a sulphated polysaccharide fraction from Gracilaria caudate (Chaves et al. 2013), a galactans from Gelidium crinale (De Sousa et al. 2013), a mucinbinding agglutinin from Hypnea cervicornis (Bitencourt et al. 2008), and a lectin from Pterocladiella capillacea (Silva et al. 2010).

4. Cosmeceutical Uses: Seaweed is rich in healthpromoting molecules such as dietary fiber, $\omega-3$ fatty acids, essential amino acids, and vitamins A, B, C, and $\mathrm{E}$ (Rajapakse et al. 2011), which is essential for cosmeceutical product development (Kim et al. 2008). 
Rhamnose moieties of ulvans backbone use to treat skin pathologies specially related with age effect. It helps to tone the skin, promotes the formation of collagen and elastin (Andrès et al. 2006; Faury et al. 2011). Marine algal compounds phlorotannins, sulphated polysaccharides and tyrosinase inhibitor compounds have been reported for its cosmeceutical importance. Oxidative stress produces reactive oxygen species (ROS) which is responsible for skin wrinkling. The methanol extract of Corallina pilulifera (CPM) have preventive ability to reduce UV-induced oxidative stress and also the expression of matrix metalloproteinase (MMPs) - MMP2 and MMP9 in human dermal fibroblast (HDF) cells. It have been suggested that the phenolic compounds from red algae have MMP inhibitory activity (Ryu et al. 2009). Tyrosinase inhibitors are responsible for skin hypo-pigmentation and enzyme catalyzes the rate-limiting step of pigmentation. Fucoxanthin isolated from Laminaria japonica suppresses tyrosinase activity (Shimoda et al. 2010). Phloroglucinol and its derivatives such as bieckol, eckol, phlorofucofuroeckol A, phlorofucofuroeckol B from Ecklonia cava, Eisenia arborea, Ecklonia bicyclis, and Ecklonia kurome have been explored for their anti-allergic effects and those investigations reveal their skin protective nature (Lee et al. 2009; Sugiura et al. 2006; Sugiura et al. 2007; Shibata et al. 2002; Shim et al. 2009). Methanol extracts, rich in phlorotannins from marine brown algae Eisenia arborea inhibit histamine release and reduce skin allergy (Sugiura et al. 2006). A new phlorotannins, phlorofucofuroeckol-B, isolated from Eisenia arborea had been used as a folk medicine in gynecopathy in Japan. The in-vitro studies on rat basophile leukaemia (RBL)-2H3 cells with phlorotannins show histamine inhibiting effect assuring the anti-allergic property (Bilan et al. 2010). Fucoidan acts as potential therapeutic agent to prevent and treat skin photoaging (Moon et al. 2009). Earons et al. 1998 noted brown seaweeds such as Fucus vesiculosus; Ascophyllum nodosum, Chondrus crispus and red seaweeds Mastocarpus stellata, Porphyra spp. were widely used as cosmetic ingredients.

5. Seaweeds for Bone development: Bone is a complex and hierarchical tissue consisting of nano hydroxyapatite and collagen as major portion. Several attempts have been made to prepare the artificial bone so as to replace the autograft and allograft treatment. Tissue engineering is a promising approach to solve the several issues and is also useful in the construction of artificial bone with materials including polymer, ceramics, metals, cells and growth factors (Venkatesan et al. 2014). Alginate, a polysaccharide extracted from brown seaweed (Laminaria hyperborea, Laminaria digitata, Laminaria japonica, Ascophyllum nodosum, and Macrocystis pyrifera) forms 3D hydrogel through ionic crosslink in the presence of $\mathrm{Ca} 2+$. Some enzymes decompose calcium alginate by generating non-poison products. So, alginate has been applied as wound cover, drug carrier, bacterial culturing substrate, etc. Calcium alginate hydrogel implant under rat skin and discover a new cartilage development. The disadvantages of calcium alginate is hard to degrade in body, so the composition and purity varies in different products (Fei et al. 2013; Lee et al. 2012; Rinaudo et al. 2008; Qin et al. 2008 (a) \&(b). It has been recently discovered that alginate beads can control the creation of calcium phosphate-one of the skeleton's essential building blocks. Alginates are biopolymers derived from seaweeds. They have the ability to thick, stabilize solutions forming gels, and use in a number of applications in both the food and medical industries. The beads show particular promise in cell transplantation. Calcium phosphate may occur in numerous forms, but inside the alginate beads the scientists find nano-sized crystals of hydroxyapatite. These have many similarities with the mineral found in bones. If the researchers succeed, the living bone mass will be implanted into skeletal injuries, such as in hip replacements, and eventually it will grow to form new functional bones out of living tissue instead

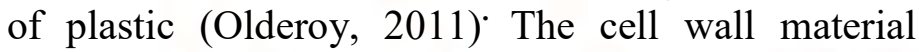
alginate of two seaweed species of Chile such as Lessonia trabeculata and Lessonia nigrescens is suitable for stem cell cultivation: it consists of a highly aqueous gel that is more viscous than honey. It cross link with calcium or barium, it is both stable and flexible like jelly, so, it can insert into the body as artificial bone cells (Zimmermann, et al. 2005). Alginate hydro gels, the polysaccharide use for small chemical drug delivery, tissue regeneration, and stimulation of blood vessel formation, bone and cartilage repair (www.sciencedaily.com). Alginate uses in cosmetics, food manufacturing and more recently in healthcare. Alginate itself use in wound dressings to keep burns moist. It has been found that after three days at a range of temperatures $4-21^{\circ} \mathrm{C}$ up to $90 \%$ of the stem cells is viable and available for healing. Medically, $70 \%$ viability is considered acceptable. Stem cells translational medicine has been described with low cost seaweed solution 
(www.sciencedaily.com). Polymer of brown seaweed supports the growth and release of stem cells at the sight of a bodily injury or at the source of a disease. The findings mark an important step in efforts to develop new medical therapies using stem cells (www.sciencedaily.com).

\section{Medicinal \& therapeutics Utilities of Iodine of} seaweeds: Iodine is supportive to thyroid, hormonal health, important for proper brain development, protecting bodies from a variety of pathogens and environmental toxin. When natural Iodine is sufficient in our diet, the thyroid will not absorb the radioactive isotope of iodine. Seaweeds especially brown seaweeds and Kelp are a rich source of Iodine. It has been investigated that the use of seaweeds as food or food ingredients are healthy to protect the health issues related to iodine deficiency. According to the UK Department of Health's Report, intakes of up to $5000 \mathrm{mcg}$ per day (i.e. over 7 grams of Ascophyllum) has shown only few cases with any issues of mild effects. The daily RDI (Dietary Reference Intake) has been recommended by the United States Institute of Medicine is between: 110 and $130 \mu \mathrm{g}$ for infants up to 12 months, $90 \mu \mathrm{g}$ for children up to eight years, 130 $\mu \mathrm{g}$ for children up to 13 years, $150 \mu \mathrm{g}$ for adults, 220 $\mu \mathrm{g}$ for pregnant women and $290 \mu \mathrm{g}$ for lactating mothers. High iodine intakes can cause toxic modular goitre and hyperthyroidism. Lack of iodine can cause developmental, structural and neural fetal abnormalities collectively called cretinism, the condition, result due to low maternal iodine supplies, is difficult to correct postpartum. The treatment is adequate maternal iodine consumption from the mother's initial beginning as an egg in her maternal grandmother (Kazutosi, 2002). Few cases of toxicity have been reported in people with intakes of less than $5000 \mathrm{mcg} / \mathrm{d}$ although transient mild effects have been demonstrated in previously in individuals receiving only $150-200 \mathrm{mcg} / \mathrm{d}$. Normal subjects with intake of $1,000-2,000 \mathrm{mcg} / \mathrm{d}$ shows an increased iodine concentration in the thyroid gland, but no other changes. An intake of $10-20 \mathrm{mg} / \mathrm{d}$ (iodine not seaweed) in Japanese fishermen has been resulted in an incidence of iodine goitre in $6-12 \%$. Kazutosi, (2002) has been reported that large brown seaweeds Laminaria sp. and kelps (Icelandic kelp, Norwegian kelp, Bullwhip kelp, Sugar kelp, Giant Pacific kelp, and Hijiki), Bladder wrack, Rockweed, Sargassum, Wakame, and Sea Palm, tend to contain more minerals per unit weight than the Red seaweeds (Nori, Irish Moss, Dulse, Grapestone, and Euchemia sp.).
Due to high Iodine, daily diet of brown seaweeds reduces the absorption of radioactive substances by the body. Iodine acts as radiation absorbing agent (Gong et al. 1991). It has been recorded that the maximum tolerate dose of $1000 \mu \mathrm{g}$ of iodine /day (Joint Food and Agriculture Organization/World Health Organization Expert Committee on Food Additives) can be reached with only small amounts of some kelp (Chapman et al. 1980).

7. Radio protective role of seaweeds: Diphlorethohydroxycarmalol (DPHC), isolate from the brown algae Ishige okamurae, notably reduces the level of radiation induced intracellular ROS and protects cells from undergoing cell death in cultured Chinese hamster lung fibroblast (V79-4) cells (Ahn et al. 2011). Fucodiphlorethol G purified from Ecklonia cava protect oxidative damage mediated apoptosis induced by ultraviolet irradiation (Kim et al. 2014). Alginates of brown seaweeds chelate with Strontium 90, help to reduce contaminations; Undaria ingestion assists in eliminating dioxins in rats (Shandala et al. 1993; Morita et al. 2002).

8. Issues about toxic trace metals of seaweeds: The mineral composition and the accumulation of heavy metal change depending on the growth environment and age of seaweeds. Uptakes of adequate amount of seaweeds with diet compensate Iodine and traceelement requirement to human body. Arsenic is considered to be toxic in the form of the inorganic salt when it consume in excess of $2 \mu \mathrm{g} / \mathrm{kg}$ body weight/day but it is also an essential trace element with a recommended minimum intake of 12-50 $\mu \mathrm{g} /$ day (Mohri et al. 1990). Seaweeds contain 10 times more minerals than land plants, so consumption of seaweeds compensates the mineral deficiencies. The high content of omega-3 fatty acids and trace elements in seaweed supports strong mental and physical health (harmonicarts.ca).

9. Conclusion: The brown seaweed such as Sargassum sp. contains bioactive compounds such as sulphated polysaccharides, plastoquinone, phlorotannins, fucoxanthin, fucoidans, Sargaquinoic acid, sargachromenol, steroids, terpenoid and flavanoid and the various extracts from this species showed significant therapeutic potential and it could be included for the preparation of novel functional component of pharmaceuticals for the treatment or prevention of several disorder. For brown seaweeds, it is remarkable to select some of the brown seaweeds as anti-cancer agent, as they are showing excellent anti- 
cancer activity. The green seaweeds and some of the red seaweeds have high amount of omega-3 fatty acids, so they have activity against some of the risk factor of cardiovascular disease.

10. Future Prospective: Many studies explore the use of seaweed in the fight against several diseases. Various therapeutic compounds from seaweed are able to induce activity through different pathways and molecular mechanisms to fight against various diseases. However, not all species of algae have health-promoting properties, as some are known to produce toxic metabolites that cause neurodegenerative disorders (Kim et al. 2011). So, this review will offer new insights on seaweeds as alternative therapeutic strategies in the treatment of different disease. As this review elaborate the species specific importance of seaweeds, it will be helpful to identify the particular species of seaweed for the progress of future research for specific disease. From this base level information, we can proceeds future research with different aspects. Although marine algae are enormous sources of a wide range of chemicals with remarkable diversity, they are not easy to isolate a large yield of desired compounds. Likely, the combinatorial genetic and metabolic engineering will be the future solution for commercial production of these compounds.

11. Conflicts of interest: There are no conflicts of interest to be declared.

12. Acknowledgements: Authors would like to acknowledge their sincere thanks Dean, Faculty of Marine Science, Annamalai University and Director, C.A. S. in Marine Biology, Annamalai University. Authors are also thankful to higher authorities of Annamalai University.

13. Funding: Authors are thankful to Department of Science \& Technology, Govt. of India, for their financial support.

\section{REFERENCES:}

1) Almeida, CL De., Hde, S Falcao., Lima, GR., Montenegro, Cde A., Lira, NS-De., AthaydeFilho, P.F., Rodrigues, L.C., DeSouza, M. F., Barbosa-Filho, J. M., Batista, L. M., (2011). Bioactivities from marine algae of the genus Gracilaria. Int. J. Mol. Sci, 12(7):4550-4573.

2) Abbassy, M. A., Marzouk, M. A., Rabea, E. I., Abd-Elnabi, A. D., (2014). Insecticidal and
Fungicidal Activity of Ulva lactuca Linnaeus (Chlorophyta) Extracts and their Fractions. Annual Research \& Review in Biology 4, 2252.

3) Ahn, M., Moon, C., Yang, W., Ko, E.J., Hyun, J. W., Joo, H. G., Jee, Y., Lee, N. H., Park, J.W., Ko, R. K, Kim, G. O. , Shin, T., (2011), Diphlorethohydroxycarmalol, isolated from the brown algae Ishige okamurae, protects against radiation-induced cell damage in mice. Food Chem Toxicol, 49(4): 864-870.

4) Ahn, M. J., Yoon, K. D., Kim, C.Y., Kim, J.H., Shin, C. G., Kim, J., (2006). Inhibitory activity on HIV-1 reverse transcriptase and integrase of a carmalol derivative from a brown alga Ishige okamurae. Phytother Res, 20, 711-713.

5) Ahn, M. J., Yoon, K. D., Min, S.Y., Lee, J.S., Kim, J.H., Kim, T.G., Kim, S.H., Kim, N.G., Huh, H., Kim, J. (2004). Inhibition of HIV-1 reverse transcriptase and protease by phlorotannins from the brown alga Ecklonia cava. Biol. Pharm. Bull. 27, 544-547.

6) Andrès, E., Molinari, J., Péterszegi, G., Mariko, B., Ruszova, E., Velebny, V., Faury, G., Robert, L., (2006). Pharmacological properties of rhamnose-rich polysaccharides, potential interest in age dependent alterations of connectives tissues. Pathol Biol. 54:420-425.

7) American Cancer Society, Cancer Facts and Figures, 2017, Atlanta, American Cancer Society

8) Akamatsu, E. Shimanaga, M. and Kamei, Y. (2003), "Isolation of an antiinfluenza virus substance, MC26 from a marine brown alga, Sargassum piluliferum and its antiviral activity against influenza virus," Coastal BioenvironmentSaga University, vol. 1, pp. 29-34,

9) Ara, J., Sultana, V., Qasim, Rahmad. V. U. (2002). Hypolipidemic activity of seaweed from Karachi coast. Phytother. Res. 16: 479-483.

10) Artan, M., Li, Y., Karadeniz, F., Lee, S. H., Kim, M. M., Kim, S. K., (2008). Anti-HIV-1 activity of phloroglucinol derivative, 6, 6 bieckol, from. Ecklonia cava Bioorg. Med. Che. 16, 7921-7926.

11) Aslam, M. N., Bhagavathula, N., Paruchuri, T., Hu, X., Chakraborty, S., Varani, J., (2009). Growth-inhibitory effects of a mineralized extract from the red marine algae, Lithothamnion calcareum, on $\mathrm{Ca}(2+)$-sensitive and $\mathrm{Ca}(2+)$ resistant human colon carcinoma cells. Cancer Lett. 283(2):186-192.

12) Athukorala, Y., Ahn, G. N., Jee, Y. H., Kim, G. Y., Kim, S. H., Ha, J. H., (2009). Antiproliferative activity of sulphated polysaccharide 
isolated from an enzymatic digest of Ecklonia cava on the U-937 cell line. Journal of Applied Phycology, 21, 307-314.

13) Awad, N. E., (2000). Biologically active steroid from the green alga Ulva lactuca. Phytotherapy Research, 14, 641-643.

14) Awad, N. E., Selim, M. A., Metawe, H. M., Matloub, A. A., (2008). Cytotoxic xenicane diterpenes from the brown alga Padina pavonia (L.) Gaill. Phytother. Res. 22: 1610-1613.

15) Ayyad, S. E., Al-Footy, K. O., Alarif, W. M., Sobahi, T. R., Bassaif, S. A., Makki, M. S., Asiri, A. M., Al Halwani, A. Y., Badria, A. F., Badria, F. A., (2011) Bioactive C15 acetogenins from the red alga Laurencia obtusa. Chem Pharm Bull. (Tokyo), 59(10): 1294-1298.

16) Barbier, P., Guise, S., Huitorel, P., Peyrot, V., 2002, Caulerpenyne from Caulerpa taxifolia has an anti-proliferative activity on tumour cell line SK-N-SH and modifies the microtubule network, Life Sciences 70(4): 415-29

17) Bilan, M. I., Grachev, A. A., Shashkov, A. S., Kelly, M., Sanderson, C. J, Nifantiev, N. E., Usov, A. I. (2010). Further studies on the composition and structure of a fucoidans preparation from the brown alga Saccharina latissima. Carbohydr. Res. 345, 2038-2047.

18) Bitencourt, F. da. S., Figueiredo, J. G., Mota, M. R., Bezerra, C. C., Silvestre, P. P., Vale, M. R., Nascimento, K. S., Sampaio, A. H., Nagano, C. S., Saker-Sampaio, S., (2008). Antinociceptive and anti-inflammatory effects of a mucin-binding agglutinin isolated from the red marine alga Hypnea cervicornis. Naunyn. Schmiedebergs. Arch. Pharmacol., 377(2):139-148.

19) Bitencourt, M. A., Dantas, G. R., Lira, D. P., Barbosa-Filho, J. M., De Miranda, G. E., Santos, B.V., Souto, J. T., (2011). Aqueous and methanolic extracts of Caulerpa mexicana suppress cell migration and ear edema induced by inflammatory agents. Mar Drugs, 9(8): 13321345.

20) Bocanegra, A., Bastida, S., Benedi, J., Rodenas, S., Sanchez-Muniz, F. J., (2009). Characteristics and nutritional and cardiovascular-health properties of seaweeds. J. Med. Food. 12:236-258.

21) Bourgougnon, N., Lahaye, M., Quemener, B., Chermann, J. C., Rimbert, M., Cormaci, M., Furnari, G., Komprobst, J. M. (1996). Annual variation in composition and in vitro anti-HIV-1 activity of the sulphated glucuronogalactan from
Schizymenia dubyi (Rhodophyta, Gigartinales). J App Phycol, 8, 155-161.

22) Campos, A., Souza, C. B., Lhullier, C., Falkenberg, M., Schenkel, E. P., Ribeiro-do-Valle, R. M., Siqueira, J. M., (2012). Anti-tumour effects of elatol, a marine derivative compound obtained from red algae Laurencia microcladia. J. Pharm. Pharmacol. 64(8): 1146-1154

23) Coombe, D. R., Parish, C. R., Ramshaw, I. W., Snowden, J. M., (1987), Analysis of the inhibition of tumour metastasis by sulphated polysaccharides, Vol. 39, Issue -1, Pages - 82-88.

24) Campo, V. L., Fábio, D., Kawano Dílson Braz da, K. D., Silva Jr. S., Carvalho, I., (2009), Carrageenans: Biological properties, chemical modifications and structural analysis - A review, Carbohydrate Polymers, Volume 77, Issue 2, Pages 167-180

25) Carlucci, M. J., Pujol, C. A., Ciancia, M., Noseda, M. D., Matulewicz, M. C., Damonte, E. B., Cerezo, A. S. (1997). Antiherpetic and anticoagulant properties of carrageenans from the red seaweed Gigartina skottsbergii and their cyclized derivatives: correlation between structure and biological activity. Int. J. Biol. Macromol. 20: 97-105

26) Castro-González, M. I., Romo, F. P. G., PérezEstrella, S., Carrillo-Dominguez, S., (1996). Chemical composition of the green alga Ulva lactuca Cienc Mar 22: 205-213.

27) Chale-Dzul, J., Moo-Puc, R., Robledo, D., FreilePelegrín, Y., (2015). Hepatoprotective effect of the fucoidan from the brown seaweed Turbinaria tricostata, Journal of Applied Phycology, 5th Congress of the International Society for Applied Phycology, Volume 27, Issue 5, pp 2123-2135

28) Chapman, V. J., and Chapman, D. J, (1980) Seaweeds and their uses, 3rd edition. London: Chapman and Hall,

29) Chaves, L. deS., Nicolau, L., A, Silva., R. O., Barros, F. C., Freitas, A. L., Aragao, K. S., Ribeiro, Rde. A., Souza, M. H., Barbosa, A. L., Medeiros, J. V., (2013). Anti-inflammatory and anti-nociceptive effects in mice of a sulphated polysaccharide fraction extracted from the marine red algae Gracilaria caudate. Immunopharmacol Immunotoxicol., 35(1): 93-100.

30) Chen, X., Nie, W., Yu G, Li Y, Hu Y, Lu J (2012) Antitumor and immunomodulatory activity of polysaccharides from Sargassum fusiforme. Food. Chem. Toxicol. 50: 695-700. 
31) Chennubhotla VSK, Kaliaperumal N, Kalimuthu S (1987) Common seaweed products, CMFRI Bulletin, 41: 26-30.

32) Celina, M. P., Guerra, D., Monique, G. D. C., Faustino, A., Luiza, S. E., Pofírio, W., Thiago, G., Costaa, D. A., Sabry, Leonardo, A. R., Rêgoa, DS., Camila, M., Accardo, Alexandre, H. O., Rochaa, Luciana Guimarães A. Filgueiraa, Leitea, E. L., (2013), A sulfated polysaccharide, fucans, isolated from brown algae Sargassum vulgare with anticoagulant, antithrombotic, antioxidant and anti-inflammatory effects. Carbohydrate Polymers- 91, 467-475.

33) Chiu, Y-H., Chan, Y-L., Li, T-L., and Wu, C-J., (2012). Inhibition of Japanese encephalitis virus infection by the sulphated polysaccharide extracts from Ulva lactuca. Marine biotechnology. 14, 468-478.

34) Coombe, D. R., Parish, C. R., Ramshaw, I. A., Snowden, J. M., (1987). Analysis of the inhibition of tumour metastasis by sulphated polysaccharides. Int. J. Cancer; 39:82-88

35) Cooper, R., Dragar, C., Elliot, K., Fitton, J. H., Godwin, J., Thompson, KGFS. (2002). A preparation of Tasmanian Undaria pinnatifida is associated with healing and inhibition of reactivation of herpes. BMC Complement Altern Med.; 2:11.

36) Costa, L. S., Fidelis, G. P., Telles, C. B., DantasSantos, N., Camara, R. B., Cordeiro, S. L., Costa, M. S., Almeida-Lima, J., Melo-Silveira, R. F., and Oliveira, R. M., (2011) Antioxidant and antiproliferative activities of heterofucans from the seaweed Sargassum filipendula. Mar. Drugs, 9(6): 952-966.

37) Damonte, E. B., Neyts, J., Pujol, C. A., Snoeck, R., Andrei, G., Ikeda, S., Witvrouw, M., Reymen, D., Haines, H., Matulewicz, M. C., Cerezo, A., Coto, C. E., De Clercq, E., (1994). Antiviral activity of a sulphated polysaccharide from the red seaweed Nothogenia fastigiata. Biochem. Pharmacol. 47: 2187-2192.

38) Daniels, B. A., (2004) Seaweed extracts composition for treatment of diabetes and diabetic complications. PCT Patent WO.103280.

39) De Sousa, A. A., Benevides, N. M., De Freitas, P. A., Fiuza, F. P., Queiroz, M. G., Morais, T. M., Pereira, M. G., Assreuy, A. M., (2013) A report of a galactans from marine alga Gelidium crinale with in vivo anti-inflammatory and Antinociceptive effects. Fundam. Clin. Pharmacol., 27(2): 173-80.
40) De Sousa, A. P. A, Torres, M. R., Pessoa, C., De Moraes, M. O., Filho, F. D. R, Nunes, Alves, A. P. N., Costa-Lotufo, L. V. (2007). In-vivo growthinhibition of Sarcoma 180 tumour by alginates from brown seaweed Sargassum vulgare. Carbohydrate Polymers, 69; 7-13.

41) Doh-ura, K., Kuge, T., Uomoto, T., Uomoto, M., Nishizawa, K., Kawasaki, Y., Iha, M., (2007). Prophylactic Effect of Dietary Seaweed Fucoidan against Enteral Prion Infection. Antimicrobial agents and Chemotherapy, vol. 51, no. 6, p. 22742277

42) Dhargakar, V. K. and Periera, N. (2005), Seaweeds Promising Plant of the millennium, Sci, Cult. $71: 60-66$.

43) Draget, K.I., Smidsrod, O., Skjak-braek, G., 2006 Alginates from algae. Biopolymer 6.

44) El Sayed, K. A., Bartyzel, P., Shen, X., Perry, T. L., Zjawiony, J. K., Hamann, M. T., (2000). Marine natural products as antituberculosis agents. Tetrahedron 56: 949-953.

45) El-Baky, H. H. A, Baz, F. K. E., Baroty, G. S. E., (2009). Potential biological properties of sulphated polysaccharides extracted from the macroalgae Ulva lactuca L. Acad. J Cancer Res 2: 01-11

46) Ellenhorn, M. J., Barceloux, D. G., Schonwald, S., and Acetaminophen in: Ellenhorn, M. J, Barceloux, D. G. (eds.) (1997). Ellenhorn's medical toxicology: Diagnosis and treatment of human poisoning. 2. ed. Baltimore: Williams \& Wilkins, 1997 p-180-195.

47) Elizondo-Gonzalez, R., Cruz-Suarez, L. E., Ricque-Marie, D., Mendoza-Gamboa, E., Rodriguez-Padilla, C., Trejo-Avila, L. M., (2012), In vitro characterization of the antiviral activity of fucoidan from Cladosiphon okamuranus against Newcastle Disease Virus; Virol J. ;9:307.

48) Faury, G., Molinari, J., Rusova, E., Mariko, B., Raveaud, S., Huber, P., Velebny, V., Robert, A. M., Robert, L. (2011). Receptors and aging: structural selectivity of the rhamnose-receptor on fibroblasts as shown by $\mathrm{Ca} 2+$-mobilization and gene-expression profiles. Arch. Gerontol. Geriat. 53: 106-112

49) Fei, Y, Li Z., Bo, L., Zhongkuan, L., (2013) Current status and prospect of artificial bone repair materials.4th International Conference on Biology, Environment and Chemistry, IPCBEE Vol.58, 17. IACSIT Press, Singapore. 
50) Fisch, K. M., Böhm, V., Wright, A. D., König, G. M., (2003). Antioxidative meroterpenoid from the brown alga Cystoseira crinita. J. Nat. Prod. 66: 968-975.

51) Fischel, J. L., Lemee, R., Formento, P., (1995). "Cell growth inhibitory effects of caulerpenyne, a sesquiterpenoid from the marine algae Caulerpa taxifolia," Anticancer Research, vol. 15, no. 5, pp. 2155-2160,

52) Francisco, C., Banaigs, B., Valls, R., Codomier, L., (1985) Mediterraneol, a novel rearranged diterpenoid-hydroquinone from the marine alga Cystoseira mediterranea. Tetrahedron. Lett. 26: 2629-2632.

53) Food and agriculture organization of the United Nations, Rome, 2012

54) Gamal-Eldeen, A. M., Ahmed, E. F., Abo-Zeid, M. A., (2009). In vitro cancer chemo preventive properties of polysaccharide extract from the brown alga, Sargassum latifolium. Food Chem Toxicol, 47(6): 1378-1384.

55) Galland-Irmouli, A-V., Fleurence, J., Lamghari, R., Luçon, M., Rouxel, C., Barbaroux, O., Bronowicki, J-P., Villaume, C., Guéant, J-L., (1999), Nutritional value of proteins from edible seaweed Palmaria palmata (dulse), The Journal of Nutritional Biochemistry, Volume 10, Issue 6, Pages 353-359

56) Garber, P., Duycher, J. D., Adams, E. G., Sherman, J. R., (1958). Protective effects of seaweed extracts for chicken embryos infected with influenza B or mumps virus. Proc. Soc. Exp. Biol. Med., 99: 590-593.

57) Ghosh, P., Adhikari, U., Ghosal, P. K., Pujol, C. A., Carlucci, M. J., Damonte, E. B., (2004). In vitro anti-herpetic activity of sulphated polysaccharide fractions from Caulerpa racemosa. Phytochemistry, 65, 3151-3157.

58) Gong, Y. F., Huang, Z. J., Qiang, M. Y., Lan, F. X., (1991). Suppression of radioactive strontium absorption by sodium alginate in animals and human subjects. Biomed Environ Sci; 4:273-282.

59) Gregson, R. P., Marwood, J. F., Quinn, R. J., (1979). The occurrence of prostaglandins PGE2 and PGF $2 \alpha$ in a plant-the red alga Gracilaria lichenoides. Tetrahedron Lett. 46: 4505-4506.

60) Gómez-Ordóñez, E., Rupérez, P., (2011) FTIRATR spectroscopy as a tool for polysaccharide identification in edible brown and red seaweeds. Food Hydrocoll 25:1514-1520

61) Grunewald, N., Groth, I., Alban, S., (2009). Evaluation of seasonal variations of the structure and anti-inflammatory activity of sulphated polysaccharides extracted from the red alga Delesseria sanguinea (Hudson) Lamouroux (Ceramiales, Delesseriaceae). Biomacromolecules, 10(5): 1155-1162.

62) Haefner, B., (2003). Drugs from the deep: marine natural products as drug candidates. Drug. Discov. Today 8: 536-544.

63) Hamann, M. T., Otto, C. S., Scheuer, P. J., Dunbar, D. C., (1996). Kahalalide: Bioactive peptides from a marine mollusc Elysia rufescens and its algal diet Bryopsis sp. J. Org. Chem. 61: 6594-6600.

64) Harada, N., Maeda, M., (1998). Chemical structure of antithrombin-active rhamnan sulphate from Monostroma nitidum. Bio. Sci. Biotechnol. 62:1647-1652

65) Hassan, S., El-Twab, S. A., Hetta, M., Mahmoud, B., (2011). Improvement of lipid profile and antioxidant of hypercholesterolemic albino rats by polysaccharides extracted from the green alga Ulva lactuca Linnaeus. Saudi. Journal of Biological Sciences. 18, 333-340.

66) Hong, D. D., Hien, H. M., and Anh, H. T. L., (2011), Studies on the analgesic and antiinflammatory activities of Sargassum swartzii (Turner) C. Agardh (Phaeophyta) and Ulva reticulata Forsskal (Chlorophyta) in experiment animal models, African Journal of Biotechnology, Vol. 10(12), pp. 2308-2314.

67) Heo, S. J., Kim, K. N., Yoon, W. J., Oh, C., Choi, Y. U., Affan, A., Lee, Y. J., Lee, H. S., Kang, D. H., (2011). Chromene induces apoptosis via caspase-3 activation in human leukemia HL-60 cells. Food Chem Toxicol; 49(9):1998-2004.

68) Hidari, K. I. P. J., Takahashi, N., Arihara, M., Nagaoka, M., Morita, K., Suzuki, T. (2008). Structure and anti-dengue virus activity of sulphated polysaccharide from marine alga. Biochem. Biophys. Res. Commun.376: 91-95

69) Hoshino, T., Hayashi, T., Hayashi, K., Hamada. J., Lee, J.B., Sankawa, U. (1998). An anti-virally active sulphated polysaccharide form Sargassum horneri. Biol. Pharm. Bull. 21:730-734

70) Hur, S., Lee, H., Kim, Y., Lee, B., Shin, J., Kim, T. (2008). Sargaquinoic acid and sargachromenol extracts of Sargassum sagamianum induced apoptosis in $\mathrm{Ha} \mathrm{Ca} \mathrm{T}$ cells and mice skin: its proliferation of UVB induced apoptosis. European Journal of Pharmacology. 582: 1-11.

71) Hwang, H., Chen, T., Nines, R. G., Shin, H. C., Stoner, G. D. (2006). Photo-chemoprevention of 
UVB-induced skin carcinogenesis in SKH-1 mice by brown algae polyphenols. Int. J. Cancer, 119, 2742-2749.

72) Hwang, P. A., Wu, C. H., Gau, S. Y., Chien, S.Y., Hwang, D. F., (2010). Antioxidant and immune stimulating activities of hot water extract from seaweed Sargassum hemiphyllum. J Mar Sci Technol., 18:41-6.

73) Hyun, J. H., Kim, S. C., Kang, J. I., Kim, M. K., Boo, H. J., Kwon, J. M., Koh, Y. S., Hyun, J. W., Park, D. B., Yoo, E. S. (2009). Apoptosis inducing activity of fucoidan in HCT 15 colon carcinoma cells. Biol. Pharm. Bull., 32, 1760-1764.

74) www.harmonicarts.com

75) Ina, A., Hayashi, K. I., Nozaki, H., Kamei, Y. (2007). Pheophytin a, a low molecular weight compound found in the marine brown alga Sargassum fulvellum, promotes the differentiation of PC12 cells. Int J Dev. Neurosci. 25:63-8.

76) Iwai, K. (2008). Anti-diabetic and antioxidant effects of polyphenols in brown alga Ecklonia stolonifera in genetically diabetic KK-A(Y) mice. Plant Foods Hum. Nutr, 63 (4):163-169

77) Jha, R. K., Zi-rong, X., (2004). Biomedical compounds from marine organisms. Mar. Drugs, 2:123-146.

78) Jin, D. Q., Lim, C. S., Sung, J. Y., Choi, H. G., Ha, I., Han, J. S. (2006) Ulva conglobata, marine algae, has neuroprotective and anti-inflammatory effects in murine hippocampal and microglial cells. Neuro. Sci. Lett. 402 (1-2):154-158.

79) Jung, W-K., Heo, S-J., Jeon, Y-J., Lee, C-M., Park, Y-M., Byun, H-G., Choi, Y-H., Park, S-G., Choi, I-W. (2009). Inhibitory Effects and Molecular Mechanism of Dieckol Isolated from Marine Brown Alga on COX-2 and iNOS in Microglial Cells. J. Agric. Food Chem. 57, 44394446

80) Kaeffer, B., Benard, C., Lahaye, M., Blottiere, H. M., Cherbut, C., (1999). Biological properties of Ulvan, a new source of green seaweed sulphated polysaccharides, on cultured normal and cancerous colonic epithelial tells. Planta Med. 65: 527-531

81) Kanke, Y., Itoi, Y., Iwasaki, M., (1996). Effects of human diets of two different Japanese populations on cancer incidence in rat hepatic drug metabolising and antioxidant enzyme systems. Nutr. Cancer. 26:63-71.

82) Kang, J. Y., Khan, M. N., Park, N. H., Cho, J.Y., Lee, M.C., Fujii, H., Hong, Y. K., (2008). Antipyretic, analgesic, and anti-inflammatory activities of the seaweed Sargassum fulvellum and Sargassum thunbergii in mice. J Ethnopharmacol. ;116(1):187-90.

83) Karthikeyan, R., Soumosundaram, S.T., Manivasagam, T., Balasubramanian, T., Anantharaman, P., (2010). Hepatoprotective activity of brown alga Padina boergesenii against $\mathrm{CCl}$ induced oxidative damage in Wistar rats, Asian Pacific Journal of Tropical Medicine, Vol. 3, Issue 9, Pages 696-701

84) Kazłowska, K., Victor, Lin HT., Chang, S. H., Tsai, G. J., (2013). In-vitro and in -vivo anticancer effects of sterol fraction from red algae Porphyra dentata Evid. Based Complement. Alternat. Med.

85) Kazutosi, N. (2002). Seaweeds Kaiso: Bountiful Harvest from the Seas. Sustenance for Health and Wellbeing.

86) Khanavi, M., Nabavi, M., Sadati, N., Shams, A. M., Sohrabipour, J., Nabavi, S. M., (2010). Cytotoxic activity of some marine brown algae against cancer cell lines. Biol. Res;43:31-7.

87) Khavani, M., Nabavi, M., Sadati, N., Ardekani, M. S., Sohrabipour, J., Savabi, S., Chaeli, P., Ostad, S., (2010). Cytotoxic activity of marine algae against cancer cell lines. Journal of Ethnopharmacology 116: 187-190.

88) Kijjoa, A., Sawangwong. P., (2004). Drugs and Cosmetics from the Sea, Mar. Drugs., 2; 73-82.

89) Kim, E. J., Park, S. Y., Lee, J. Y., Park, J. H., (2010). Fucoidan present in brown algae induces apoptosis of human colon cancer cells. BMC. Gastroenterol. 10, 96.

90) Kim, J., Cho, Y., Jung, W., Kim, M., Kim, S. (2008). Antioxidative effect of methanolic extract of Sargassum thunbergii in macrophage RAW264.7 and HL60. Journal of Biotechnology 120: 418-425.

91) Kim, K-C., Piao, M-J., Zheng, J., Yao, C-W., Cha, J-W., Kumara, M.H.S.R., Xia, Han, X., Kang, H-K., Nam, Ho. Lee N-H., Hyu, W-J. (2014). Fucodiphlorethol G Purified from Ecklonia cava Suppresses Ultraviolet B Radiation Induced Oxidative Stress and Cellular Damage. Biomolecules \& Therapeutics; 22(4): 301307.

92) Kim, M. S., Kim, J. Y., Choi, W. H., Lee, S. S. (2008). Effects of seaweed supplementation on blood glucose concentration, lipid profile, and antioxidant enzyme activities in patients with type 2 diabetes mellitus. Nutrition Research and Practice, 2(2), 62-67 
93) Kim, S. K., Li, Y. X., (2011). Medicinal benefits of sulphated polysaccharides from sea vegetables. Adv Food Nutr Res., 64:391-402

94) Kim, S. K., Ravichandran, Y. D., Khan, S. B., and Kim, Y. T. (2008) Prospective of the cosmeceutical derived from marine organisms. Biotechnol. Bioprocess Eng. 13, 511-523.

95) Kimiya, T., Ohtani, K., Satoh, S., Abe, Y., Ogita. Y., Kawakita, H., (2008), Inhibitory effects of edible marine algae extracts on degranulation of RBL-2H3 cells and mouse eosinophils. Fish Sci; Vol. 74, no. 5 pp. 1157-65.

96) Kim, Y. M., Kim, I. H., Nam, T. J., (2012). Induction of apoptosis signaling by glycoprotein of Capsosiphon fulvescens in human gastric cancer (AGS) cells. Nutr. Cancer, 64(5):761-769.

97) Kumari, P., Bijo, A. L., Mantri, V. A., Reddy, C. R. K. and Jha, B. 2013. Fatty acid profiling of tropical marine macroalgae: An analysis from chemotaxonomic and nutritional perspectives. Phytochemistry 86:44-56

98) Kwon, M. J., \& Nam, T. J., (2006), Porphyran induces apoptosis related signal pathway in AGS gastric cancer cell lines. Life Sci. 79(20):1956-62.

99) La, Barre, S., Potin, P., Leblanc, C., Delage, L., (2010). The halogenated metabolism of brown algae (Phaeophyta), its biological importance and its environmental significance. Mar. Drugs. 8, 988-1010.

100) Lahaye, M., Brunel, M., and Bonnin, E., 1997. Fine chemical structure analysis of oligosaccharides produced by an ulvanlyase degradation of the water-soluble cell-wall polysaccharides from Ulva sp. (Ulvales, Chlorophyta). Carbohydrate Research, 304 (3-4): 325-333.

101) Lawson, J. S., Tran, D., Rawlinson, W. D., (2001). From Bittner to Barr: A viral, diet and hormone breast cancer aetiology hypothesis. Breast Cancer Res. 3: 81-85.

102) Lee, D-G., Hyun, J-W., Kang, K-A., Lee, J-O., Lee, S-H., Ha, B-J., Ha, J-M., Lee, E. Y., Lee, JH. (2004). Ulva lactuca potential seaweed for tumor treatment and immune stimulation. Biotechnology and Bioprocess Engineering 9, 236-238.

103) Lee, H., Kim, J-S., Kim, E., (2012). Fucoidan from seaweed Fucus vesiculosus inhibits migration and invasion of human lung cancer cell via PI3K-Akt-mTOR Pathways. PLOS ONE: fucoidan inhibits cancer cell metastasis; Vol.7, Issue 11,
104) Lee, H. J., Dang, H.T., Kang, G. J., Yang, E. J., Park, S.S., Yoon, W. J., Jung, J. H., Kang, H. K., Yoo, E. S., (2009). Two enone fatty acids isolated from Gracilaria verrucosa suppress the production of inflammatory mediators by downregulating NFkappaB and STAT1 activity in lipopolysaccharide-stimulated RAW 264.7 cells. Arch Pharm Res, 32(3): 453-462.

105) Leiro, J. M., Castro, R., Arranz, J. A., Lamas, J., (2007). Immunomodulating activities of acidic sulphated polysaccharides obtained from the seaweed Ulva rigida C. Agardh. International Immunopharmacology, 7, 879-888.

106) Li, H., Wang, X., Li, P., Li, Y., Wang, H., (2008) Comparative study of antioxidant activity of Grape (Vitis vinifera) seed powder assessed by different methods. Journal of Food and Drug Analysis 16 (6): 67-73.

107) Luscher-Mattli, M., (2000). Polyanions-a lost chance in the fight against HIV and other virus diseases? Antiviral Chem Chemother; 11: 249259.

108) Love, J., \& Percival, E., (1964). The polysaccharides of the green seaweed Codium fragile part-II, the water-soluble sulphated polysaccharides. Journal of the chemical Sciety, 3338-3345.

109) Love, J., \& Percival, E., (1964b). The polysaccharides of the green seaweed Codium fragile, part-II, A- $\beta$-1-4- linked mannan, Journal of the chemical Society, 3345-3349.

110) Manoharan, N., Sampathkumar, P., Dheeba, B., Sheikabdulla, S., Vinothprasanna, G., Vinothkannan, R., Kalavathy, S., Vijayaanand, A., Shanmugasundaram, A., (2008). Potential hepatoprotective effect of aqueous extract of Gracilaria corticata in afb1 induced hepatotoxicity in Wistar rats. J. BIOL. SCI., V. 8, N.8, p.1352-1355.

111) Mao, W., Zang, X., Li, Y., Zhang, H. (2006), Sulphated polysaccharides from marine green algae Ulva conglobata and their anticoagulant activity. J. Appl. Phycol. 18:9-14

112) Mabeau, S., Kloareg, B., 1987, Isolation and analysis of the cell walls of brown algae: Fucus spiralis, F. ceranoides, F. vesiculosus, F. serratus, Bifurcaria bifurcata and Laminaria digitata. Journal of Experimental Botany; $38: 1573-1580$

113) Mckinnell, JP; Percival, E. Acid polysaccharide from green seaweed. Ulva-lactuca. J. Chem. Soc 1962, 2082-2083. 
114) Margret, R. J., Kumaresan, S., Ravikumar, S., (2009). A preliminary study on the antiinflammatory activity of methanol extract of Ulva lactuca in rat. J Environ Biol. 2009 Sep; 30 (5 Suppl): 899902.

115) Matsubara. K., Matsuura, Y., Bacic, A., Liao, M-L., Hori, K., Miyazawa, K., (2001) Anticoagulant properties of a sulfated galactan preparation from a marine green alga, Codium cylindricum. International Journal of Biological Macromolecules 28: 395-399.

116) Mandal P, Mateu CG, Chattopadhyay K, Pujol CA, Damonte EB, Ray B (2007) Structural features and antiviral activity of sulphated fucans from the brown seaweed Cystoseira indica. Antivir Chem Chemother 18:153-162

117) Matsubara, K.; Matsubara, Y.; Hori, K. and Miyazawa, K. (2000), An anticoagulant proteoglycan from the marine green alga, Codium pugniformis. J. Appl. Phycol., 12, 9-14.

118) Mayer, A. M., Glaser, K. B., Cuevas, C., Jacobs, R. S., Kem, W., Little, R. D., McIntosh, J. M., Newman, D. J., Potts, B. C., Shuster, D. E., (2010). The odyssey of marine pharmaceuticals: a current pipeline perspective. Trends Pharmacol Sci. 31(6):255-265.

119) Mayer, A.M.S, Paul, V.J., Fenical, W., Norris, J.M., De Carvalho, M. S., Jacobs, R. S., (1993). Phospholipase A2 inhibitors from marine algae. Hydrobiologia, 260/261: 521-529.

120) Mazumder, S., Ghosal, P. K., Pujol, C. A., Carlucci, M. J., Damonte, E. B., Ray, B. (2002). Isolation, chemical investigation and antiviral activity of polysaccharides from Gracilaria corticata (Gracilariaceae, Rhodophyta). Int. J. Biol. Macromol. 31: 87-95.

121) Moen, L. K. and G. F. Clark. 1993. A novel reverse transcriptase inhibitor from Fucus vesiculosus. Int. Conf. AIDS 9:145-161.

122) Mohri, T., Hisanaga, A., Ishinishi, N. (1990), Arsenic intake and excretion by Japanese adults: A 7-day duplicate diet study. Food Chem Toxicol; 28 (7): 521-529.

123) Molinski, T., (2009), Marine natural products. Clinical advances in haematology \& oncology: $\mathrm{H} \& \mathrm{O}, 7(6): 383-385$

124) Mori, H., Kamei, H., Nishide, E., Nisizawa, K., (1982), Sugar constituents of some sulphated polysaccharides from the sporophylls of wakame and their biological activities. In: Hoppe HA, Levring T, eds. Marine Algae in Pharmaceutical
Science, vol. 2. New York \& Berlin: Walter de Gruyter: 109-121.

125) Morita, K., Nakano, T., (2002), Seaweed accelerates the excretion of dioxin stored in rats. J. Agric. Food Chem.13; 50: 910-917.

126) Mouritsen, O.G., (2013) Seaweeds edible, available, \& sustainable. J. ENVIRM. Biol. 30899-902

127) Murugan, A., (2011) Pharmaceutical and nutraceuticals values of marine algae. Souvenir, National Conference on Algae and Algal Products. Sathyabama, University, Chennai. pp. 85-90.

128) Na, H. J., Moon, P. D., Ko, S. G., Lee, H. J., Jung, H. A., Hong, S. H., (2005) Sargassum hemiphyllum inhibits atopic allergic reaction via the regulation of inflammatory mediators. J. Pharmacol Sci, 97: 219-26.

129) Namvar, F., Mahamad, R., Baharara, J., Balnejah, S. Z., Fargahi, F., Rahman, H. S. (2013), Antioxidant, Anti-proliferative, and antiangiogenesis effects of polyphenol rich seaweed (Sargassum muticum). Biomed. Res. Int. 604787.

130) Namvar, F., Mohamed, S., Fard, S-G., Behravan, J., Mustapha, N-M., Alitheen, N-B-M., Othman, F., (2012) Polyphenol-rich seaweed (Eucheuma cottonii) extract suppresses breast tumour via hormone modulation and apoptosis induction. Food Chemistry, 130, 376-382

131) Nishino, H., Murakoshi, M., Ii, T., Takemura, M., Kuchide, M., Kanazawa, M., Mou, X. Y., Wada, S., Masuda, M., Ohsaka, Y., Yogosawa, S., Satomi, Y., Jinno, K., (2002) Carotenoid in cancer chemoprevention. Cancer Metastasis Rev 21(34):257-264.

132) Nishino, T., Nishioka, C., Ura, H., Nagumo, T. (1994) Isolation and partial characterization of a novel amino sugar-containing fucan sulphate from commercial Fucus vesiculosus fucoidans. Carbohydr Res. 255:213-224.

133) Numata, A., Kanbara, S., Takahashi, C., Fujiki, R., Yoneda, M., Usami, Y. (1992), A cytotoxic principle of the brown alga Sargassum tortile and structures of chromene. Phytochemistry. 31:1209-13.

134) Okada Y, Ishimaru A, Suzuki R, Okuyama T. (2004), A new phloroglucinol derivative from the brown alga Eisenia bicyclis: Potential for the effective treatment of diabetic complications. J Nat Prod, 67, 103-105

135) Olderøy, M. O., Xie, M., Strand, B. L., Draget, K. I., Sikorski, P., and Andreassen, J-P., 
(2011). Polymorph Switching in the Calcium Carbonate System by Well-Defined Alginate Oligomers, Cryst. Growth, 11 (2), pp 520-529.

136) Palermo, J. A., Flower, P. B., Seldes, A. M. (1992), "Chondriamides-A and B, new indolic metabolites from the red alga Chondria sp," Tetrahedron Letters, vol. 33, no. 22, pp. 3097310.

137) Pangestuti, R., and Kim, S.K., (2011) Neuro protective effects of marine algae. Mar. Drugs, 9: 803-818.

138) Park, H.K., Kim, I.H., Kim, J., Nam, T. J., (2012), Induction of apoptosis by laminarin, regulating the insulin like growth factor-IR signaling pathways in HT-29 human colon cells. Int. J. Mol. Med. 30, 734-738.

139) Park, H. K., Kim, J., Nam, T. J., (2013), Induction of apoptosis and regulation of ErbB signaling by laminarin in HT-29 human colon cancer cells. Int. J. Mol. Med. 32, 291-295.

140) Pengzhan, Y., Quanbin, Z., Ning, L., Zuhong, X., Yanmei, W., Zhi'en, L., (2003) Polysaccharides from Ulva pertusa (Chlorophyta) and preliminary studies on their antihyperlipidemic activity. Journal of applied Phycology, 15, 21-27.

141) Pereira, D. M., Cheel, J., Arche, C., SanMartin, A., Rovirosa, J., Silva, L. R., Valentao, P., Andrade, P. B., (2011), Anti-proliferative activity of meroditerpenoids isolated from the brown alga Stypopodium flabelliforme against several cancer cell lines. Mar. Drugs, 9, 852-862.

142) Percival, E. and McDowell, R. H. (1967), Chemistry and enzymology of marine algal polysaccharides. Academic Press, New York

143) Queiroz, K. C. S., Medeiros, V. P., Queiroz, L. S., Abreu, L. R. D. Rocha, H.A.O., Ferreira, C. V., Juca, M. B., Aoyama, H., Leite, E. L., (2008), Inhibition of reverse transcriptase activity of HIV by polysaccharides of brown algae. Biomed. Pharmacother. 62, 303-307.

144) Qin, Y.,(2008a), Alginate fibres: an overview of the production processes and applications in wound management, Polymer International, 57, 171-108

145) Qin, Y., (2008b), The gel swelling properties of alginate fibres and their applications in wound management, Polymer for Advanced Technologies, 19, pp. 6-14

146) Raman, B.V., Rao, D. N., Radhakrishnan, T.M., (2004), Enteromorpha compressa (L.) Greville and edible green alga as a source of anti- allergic principle (S). Indian. J. Clin. Biochem; 19:105-9.

147) Ray B. Polysaccharides from Enteromorpha compressa: Isolation, purification and structural features. Carbohydr. Polym. 2006; 66 : 408-416.

148) Religa, P., Kazi, M., Thyberg, J., Gaciong, Z., Swedenborg, J., Hedin, U. (2000). Fucoidan inhibits smooth muscle cell proliferation and reduces mitogen-activated protein kinase activity. Eur J Vasc Endovasc Surg. 20:419-426

149) Rinaudo, M.,(2008), Main properties and current applications of some polysaccharides as biomaterials, Polymer International, 57, pp. $397-$ 430

150) Recknagel R O, 1967 Carbon tetrachloride hepatotoxicity. Pharmacol. rev., v.19, n.2, p.145208.

151) Rajapakse, N.; Kim, S. K., (2011) Nutritional and Digestive Health Benefits of Seaweed. In Advances in Food and Nutrition Research; Kim, S. K., Ed.; Academic Press: San Diego, CA, USA, Volume 64, pp. 17-28.

152) Ritter, L. S., Copeland, J. G., and McDonagh, P. F. (1998), Fucoidan reduces the coronary micro vascular leukocyte accumulation early in reperfusion. Ann Thorac. Surg; 66: 2063-2071.

153) Rodrigues, J. A. G., Vanderlei, E. De Sousa, O., Bessa, E. F., Magalhães, F. De A., Paula, R. C $\mathrm{M}$ de Lima, V., and Benevides, N. M. B., Anticoagulant Activity of a Sulphated Polysaccharide Isolated from the Green Seaweed Caulerpa cupressoides. Braz. Arch. Biol. Technol. V.54 N.4: pp. 691-700, 2011

154) Ryu, B., Qian, Z-J., Kim, M-M., Nam, K.W., Kim, S-K, (2009), Anti-photoaging activity and inhibition of matrix metalloproteinase (MMP) by marine red alga, Corallina pilulifera methanol extract. Radiat. Phys. Chem. 78, 98-105.

155) Ryu, M-J., Kim, A. D., Kang, K. A., Chung, H-S., Kim, H-S., Suh, I-S., Chang, W-Y., Hyun, JH. (2013), the green algae Ulva fasciata Delile extract induces apoptotic cell death in human colon cancer cells. In Vitro Cellular \& Developmental Biology-Animal, Vol. 49, Issue 1, pp 74-81.

156) Samee, H., Li, Z.X., Lin, H., Khalid, J., Guo, Y.C., (2009) Anti-allergic effects of ethanol extracts from brown seaweeds. J. Zhejiang Univ. Sci. B, 10:147-5

157) Sathivel, A., Balaji, Raghavendran, H. R., Srinivasan, P., Devaki, T. (2008), Anti-per oxidative and anti-hyperlipidemic nature of Ulva 
lactuca crude polysaccharide on D-galactosamine induced hepatitis in rats. Food Chem. Toxicol. 46:3262-3267

158) Sánchez-Machado Di, López-Hernández J, Paseiro-Losada P, López-Cervantes J, (2004), An HPLC method for the quantification of sterols in edible seaweeds. Biomed Chromatogr. (3):18390.

159) Schaeffer, D. J., Krylov, V. S., (2000). Anti HIV activity of extracts and compounds from algae and cyanobacteria: Ecotoxicology and environmental safety; 45:208-227.

160) Shandala, N. K. (1993), Alimentary methods for decreasing the radiation load of the body with cesium and strontium radionuclides [in Russian]. Gig Sanit. 10:51-54.

161) Shimoda, H., Tanaka, J., Shan, S. J., Maoka, T. (2010), Anti-pigmentary activity of fucoxanthin and its influence on skin mRNA expression of melanogenic molecules. J. Pharm. Pharmacol. Res. 62, 1137-1145.

162) Shin, E. S., Hwang, H. J., Kim, I. H., Nam, T. J. (2011), A glycoprotein from Porphyra yezoensis produces anti-inflammatory effects in liposaccharide stimulated macrophages via the TLR4 signaling pathway. Int J Mol Med. 28(5): 809-815

163) Silva, L. M., Lima, V., Holanda, M. L., Pinheiro, P. G., Rodrigues, J. A., Lima, M. E., Benevides, N. M. (2010), Antinociceptive and anti-inflammatory activities of lectin from marine red alga Pterocladiella capillacea. Biol. Pharm. Bull., 33(5):830-835.

164) Simopoulos, A. P. (1991), Omega-3 fatty acids in health and disease and in growth and development. Am. J Clin. Nutr. 54(3):438-46.

165) Spavieri, J., Kaiser, M., Casey, R., HingleyWilson, S., Lalvani, A., Blunden, G., Tasdemir, D., 2010b. Antiprotozoal, antimycobacterial and cytotoxic potential of some british

166) Spieler, R., (2002) Seaweed compound's antiHIV efficacy will be tested in southern Africa. Lancet 359: 1675.

167) Taboada, C., Millán, R., Míguez, I., (2010), Composition, nutritional aspects and effect on serum parameters of marine algae Ulva rigida. J Sci Food Agric., 90(3):445-9.

168) Talyshinsky, M. M., Souprun, Y. Y., Huleihel, M. M., (2002) Anti-viral activity of red microalgal polysaccharides against retroviruses. Cancer Cell Int, 2(1):8.
169) Teas, J. (1983), the dietary intake of Laminaria, a brown seaweed, and breast cancer prevention. Nutr Cancer; 4(3):217-222.

170) Trento, F., Cattaneo, F., Pescador, R., Porta, R., Ferro, R., (2001) Antithrombin activity of an algal polysaccharide. Thromb. Res. 102: 457-465.

171) Vanderlei, E. S., Patoilo, K. K., Lima, N. A., Lima, A. P., Rodrigues, J. A., Silva, L. M., Lima, M. E., Lima, V., Benevides, N. M., (2010) Antinociceptive and anti-inflammatory activities of lectin from the marine green alga Caulerpa cupressoides. Int. Immunopharmacol., 10(9):1113-1118.

172) Vasanthi, H. R., Rajamanickam, G. V., Saraswathy, A., Jaswanth, A. (2004) Tumoricidal effect of the red algae Acanthophora spicifera on Ehrlich's ascites carcinoma in mice. Seaweed Res. util., 25 217-223.

173) Venkatesan, J., Bhatnagar, I., Kim, S-K., (2014), Chitosan-alginate bio composite containing fucoidans for bone tissue engineering. Mar. Drugs 12, 300-316.

174) Vischer, P., Buddecke, E., (1991). "Different action of heparin and fucoidans on arterial smooth muscle cell proliferation and thrombospondin and fibronectin metabolism," European Journal of Cell Biology, vol. 56, no. 2, pp. 407- 414

175) Wang, H., Chiu, L.C.M., Ooi, V.E.C., and Ang, P.O. (2008), Seaweed polysaccharides with anticancer potential. Bot. Mar. 51:313-319.

176) Wang, S. C., Bligh, S. W. A., Shi, S. S., Wang, Z. T., Hu, Z. B., Crowder, J., Branford White, C., Vella, C. (2007), Structural features and anti-HIV-1 activity of novel polysaccharides from red algae Grateloupia longifolia and Grateloupia filicina. Int. J. Biol. Macromol, 41, 369-375.

177) W.,Wang, S-X., and Guan, H-S., (2012), The Antiviral Activities and Mechanisms of Marine Polysaccharides: An Overview, Mar. Drugs ,10(12), 2795-2816

178) WCRF/AICR (2009) Food, Nutrition, Physical Activity and Prevention of Cancer: A Global Perspective; American Institute for Cancer Research: Washington, DC, USA

179) Witvrouw, M, De Clercq, E. (1997), Sulphated polysaccharides extracted from sea algae as potential anti-viral drugs. Gen Pharmacol, 29: 497-511.

180) Witvrouw, M., Este, J. A., Mateu, M. Q., Reymen, D., Andrei, G., Snoeck, R., Ikeda, S., Pauwels, R., Bianchini, N. V., Desmyter, J., de 
Clercq., E. (1994), Activity of a sulphated polysaccharide extracted from the red seaweed Aghardhiella tenera against human immunodeficiency virus and other enveloped viruses. Antiviral Chem. Chemotherapy, 5: 297303.

181) Wong, K. H., Sam, S. W., Cheung, P. C. K., Ang PO (1999) Changes in lipid profiles of rats fed with seaweed-based diets. Nutr Res.; 19:15191527

182) https://www.ncbi.nlm.nih.gov/PubMed

183) Xue, M., GE, Y., Zhang, J., Wanq., Q., Hou, L., Liu, Y., Sun, L., Li, Q., (2012) Anticancer properties and mechanisms of fucoidan on mouse breast cancer in vitro and in vivo. PLoS, 7

184) Yang, J. I., Yeh, C. C., Lee, J. C., Yi, S. C., Huang, H. W., Tseng, C. N., Chang, H. W. (2012), Aqueous extracts of the edible Gracilaria tenuistipitata are protective against $\mathrm{H} 2 \mathrm{O} 2$-induced DNA damage, growth inhibition, and cell cycle arrest. Molecules, 17(6):7241-7254

185) Ye, H., Wang, K., Zhou, C., Liu, J., Zeng, X. (2008) Purification, antitumor and antioxidant activities in vitro of polysaccharides from the brown seaweed Sargassum pallidum. Food Chem.;111:428-32.

186) Yeh, C. C., Tseng, C. N., Yang, J. I., Huang, H. W., Fang, Y., Tang, J. Y., Chang, F. R., Chang, H .W. (2012), Antiproliferation and induction of apoptosis in $\mathrm{Ca} 9-22$ oral cancer cells by ethanolic extract of Gracilaria tenuistipitata. Molecules, 17(9):10916-10927.

187) Yokota, T., Ehlin-Henriksson, B., Hansson, G. K., (1988), Scavenger receptors mediate adhesion of activated B lymphocytes. Exp Cell Res. 239:1:16-22.

188) Yoshie, Y., Wang, W., Hsieh, Y.P., Suzuki, T. (2002), "Compositional difference of phenolic compounds between two seaweeds, Halimeda spp.," Journal of Tokyo University Fisheries, vol. 88, pp. 21-24.

189) Yoshizawa, Y., Enomoto, A., Todoh, H., Ametani, A., Kaminogawa, S. (1993) Activation of murine macrophages by polysaccharide fractions from marine algae (Porphyra yezoensis). Bioscience, Biotechnology and Biochemistry, 57(11), 1862-1866.

190) Yuan, Y. V., Carrington, M. F., Walsh N. A. (2005), "Extracts from dulse (Palmaria palmata) are effective antioxidants and inhibitors of cell proliferation in vitro," Food and Chemical Toxicology, vol. 43, no. 7, pp. 1073-1081.
191) Yoon, W-J., Ham, Y. M., Kim, S-S.,Yoo, BS., Moon, J-Y., Baik, J. S., Lee, N. H., Hyun, CG., (2009). Suppression of pro-inflammatory cytokines, iNOS, and COX-2 expression by brown algae Sargassum micracanthum in RAW 264.7 macrophages. EurAsian Journal of BioSciences, 130-143.

192) Zhang, H.J.; Mao, W.J.; Fang, F.; Li, H.Y.; Sun, H.H.; Chen, Y. and Qi, X.H. (2008), Chemical characteristics and anticoagulant activities of a sulfated polysaccharide and its fragments from Monostroma latissimum. Carbohydr. Polym., 71, 428-434.

193) Zandi, K., Ahmadzadeh, S., Tajbakhsh, S., Rastian, Z., Yousefi, F., Farshadpour, F., Sartavi, K. (2010), Anticancer activity of Sargassum oligocystum water extract against human cancer cell lines. Eur Rev Med Pharmacol Sci, 14(8):669673.

194) Zhu, W. Ooi, VEC. Chan, PKS., Ang, Jr. P. O., (2003). Inhibitory effect of extracts of marine algae from Hong Kong against Herpes simplex viruses. In Chapman ARO, Anderson RJ, Vreeland VJ, Davison IR (eds.), Proceedings of the 17th International Seaweed Symposium, Oxford University Press, Oxford, pp. 159-164.

195) Zhang, J., Tiller, C., Shen, J., Wang, C., Gabrielle, S., Girouard, Dennis, D., Colin, J., Barrow, M. M., and Ewart, H. S., (2007). Antidiabetic properties of polysaccharide- and polyphenolic-enriched fractions from the brown seaweed Ascophyllum nodosum Can. J. Physiol. Pharmacol. 85: 1116-1123.

196) Zimmermann H, Zimmermann D, Reuss R., (2005) Towards a medically approved technology for alginate-based microcapsules allowing longterm immunoisolated transplantation. J Mater Sci Mater Med 16:491-501

197) Zhuang, C., Itoh, H., Mizuno, T., Ito, H., (1995). Antitumor Active Fucoidan from the Brown Seaweed, Umitoranoo (Sargassum thunbergii). Biosci Biotechnol Biochem. 59(4):563-7 